\title{
A Dimensão Axiológica na Elaboração de uma Rede Temática na Educação Infantil: Contribuições para o Ensino de Ciências
}

\section{The Axiological Dimension in the Elaboration of a Thematic Network in Early Childhood Education: Contributions to Science Teaching}

\author{
Jefferson da Silva Santos \\ Josenilda Assunção Lima \\ Brasil \\ Leticia dos Santos Barbosa \\ Brasil \\ Simoni Tormohlen Gehlen \\ Brasil \\ Brasil
}

Estudos na área de Educação em Ciências, pautados na perspectiva freireana, têm organizado a estruturação curricular baseando-se em Temas Geradores, em que a Rede Temática assume o papel de instrumento pedagógico para a compreensão de contradições sociais. Embora existam trabalhos que discutam a dimensão ética e política dos currículos e da prática pedagógica, entendemos que necessita-se evidenciar os valores envolvidos na construção da Rede Temática. Portanto, investigamos a compreensão de duas educadoras da Educação Infantil acerca dos valores presentes na construção de uma Rede Temática, durante um processo formativo pautado na Investigação Temática, realizado numa escola do município de Ilhéus/BA. As informações foram obtidas por meio de entrevistas semiestruturadas e videogravações e analisadas mediante a Análise Textual Discursiva, com base nas categorias a posteriori: Os valores na interação entre escola e comunidade; Os valores na programação curricular de ciências. Evidenciamos que o diálogo, interação, participação, envolvimento, conscientização, coletividade, humanização, o comprometimento com o outro e o conhecimento significativo são valores imprescindíveis para uma relação dialógica entre comunidade e escola. $\mathrm{Na}$ elaboração das Unidades de Conhecimentos de Ciências, constatamos que a criticidade, a responsabilidade pelo outro, o respeito pelas diferentes visões de mundo e o prazer são valores que emergem da compreensão das educadoras em relação a organização curricular baseada nos pressupostos freireanos. Portanto, consideramos que a reflexão e discussão sobre os valores no âmbito educativo podem contribuir para formação da consciência ético-crítica, reconhecimento e fortalecimento dos valores da cultura local, elaboração de currículos populares, propiciando a efetivação de projetos pedagógicos libertadores. 
Palavras-chave: Rede Temática; Educação Infantil; Valores; Paulo Freire; Educação em Ciências.

Research in ScienceEducation based on Freire's perspective has organized the curriculum structuring rested on Generating Themes, in which the Thematic Network assumes the role of a pedagogical instrument for the understanding of social contradictions. Although there are studies that discuss the ethical and political dimensions of curricula and pedagogical practices, we understand that it is necessary to highlight the values involved in the construction of the Thematic Network. Therefore, we investigate the understanding of two preschool teachers regarding the values present in the construction of a Thematic Network, during a training process based on Thematic Research, held in a school in the Brazilian city of Ilhéus/BA. Information was obtained through semistructured interviews and video recordings, which were analyzed through Discursive Textual Analysis, founded on the following a posteriori categories: Values in the interaction between school and community; Values in science curriculum planning. We provided that dialogue, interaction, participation, involvement, awareness, collectivity, humanization, commitment to each other and meaningful knowledge are indispensable values for a dialogical relationship between community and school. In the elaboration of the Science Knowledge Units, we found that criticality, responsibility for others, respect for different worldviews, and pleasure are values that emerge from the teachers' understanding of the curricular organization based on Freirean assumptions. Therefore, we consider that reflection and discussion about values in the field of education can contribute to the formation of ethical-critical awareness, recognition and strengthening of the values of local culture, elaboration of popular curricula, enabling the realization of liberating pedagogical projects.

Keywords: Thematic Network; Child Education; Values; Paulo Freire; Science Education.

\section{Introdução}

Algumas pesquisas na área de Educação em Ciências vêm sendo desenvolvidas com base em aportes teórico-metodológicos do educador Paulo Freire para auxiliarem em aspectos como a reestruturação e elaboração de currículos escolares baseados em Temas Geradores, envoltos em contradições sociais vivenciadas por educandos, educadores e comunidade (Centa, \& Muenchen, 2018; Delizoicov, 1982; Furlan, 2015; Mendonça, 2016; Milli, Solino, \& Gehlen, 2018a; Rambo, 2017; Silva, 2004; Stuani, 2016). A compreensão crítica dessas contradições sociais revela os mecanismos de perpetuação das relações de opressão construídas historicamente, que estão alicerçados em uma ética hegemônica e excludente, ou seja, um sistema que suprime os valores das vítimas negadas historicamente e preconiza os valores da cultura opressora (Dussel, 2013). Desse modo, sendo a ética um "conjunto estruturado de atitudes que predeterminam a ação" (Dussel, 1977, p. 61), compreendemos que no âmbito educacional as práticas exercidas 
pela comunidade escolar apresentam uma dimensão axiológica, visto que podem se configurar como transformadoras ou perpetuadoras do sistema vigente.

No contexto dessa discussão, Silva (2004) e Furlan (2015) destacam duas questões importantes: a preocupação sobre a ética que fundamenta a construção dos currículos e a ética que orienta a prática docente, em que o princípio ético-crítico tem contribuído para a construção de currículos populares e críticos, abrangendo o sistema de valores das vítimas excluídas pelo sistema hegemônico. O princípio ético-crítico, enquanto alicerce curricular e da prática docente, fomenta a criação de uma práxis libertadora, uma vez que:

O ato pedagógico ocorre apenas no processo de liberar a práxis. Esse processo não se refere apenas a um ato revolucionário, mas a todo ato transformador humanizador em favor dos oprimidos e no interesse de superar a própria condição de opressão (Dussel, 2013, p. 320, tradução nossa).

O movimento de reorientação curricular crítica, fundamentada nesta perspectiva, traz para o âmbito escolar uma compreensão ético-crítica da realidade da comunidade na qual está inserida, por meio da problematização e da dialogicidade, considerando os educandos agentes transformadores dessa realidade (Silva, 2004).

A identificação dos Temas Geradores segue o processo de Investigação Temática, elaborado inicialmente por Freire (1987) e adaptado por Delizoicov (1982) para a educação escolar nas seguintes etapas: 1) Levantamento Preliminar: reconhecimento local da comunidade; 2) Codificação: análise e escolha das possíveis contradições sociais vivenciadas pelos indivíduos; 3) Descodificação: legitimação dessas situações e sintetização em Temas Geradores; 4) Redução Temática: seleção de conteúdos e conhecimentos científicos para a compreensão do Tema Gerador e construção do planejamento de ensino; 5) Desenvolvimento em Sala de Aula: implementação de atividades didático-pedagógicas com os educandos.

No processo de Redução Temática ocorre a cisão do Tema Gerador enquanto totalidade, para que suas partes constituam as unidades temáticas que representam a totalidade programática, ou seja:

$\mathrm{Na}$ "redução temática", que é uma operação de "cisão" dos temas enquanto totalidades se buscam seus núcleos fundamentais, que são as suas parcialidades. Desta forma, "reduzir" um tema é cindi-lo em suas partes para, voltando-se a ele como totalidade, melhor conhecê-lo (Freire, 1987, p. 67).

Portanto, a Redução Temática consiste em um mecanismo que permite uma compreensão das realidades parciais sintetizadas nas situações-limites. Além de possibilitar a construção e organização curricular com base na seleção de conceitos, conteúdos e ações das diversas áreas do conhecimento, permitindo uma compreensão do Tema Gerador em sua totalidade.

Silva (2004) propôs a elaboração de uma Rede Temática nesta etapa como um instrumento pedagógico com o objetivo de organizar a análise relacional e sistêmica 
da realidade, em que os sujeitos em situação de opressão estão imersos. Ou seja, a Rede Temática é uma "forma de registro dos diferentes discursos, na perspectiva de propiciar um distanciamento analítico [...] para o discernimento crítico das visões dos envolvidos sobre a realidade, possibilita superar muitas das dificuldades anteriormente relatadas" (Silva, 2004, p. 239). Assim, é possível relacionar as falas significativas dos sujeitos, que expressam diferentes percepções da realidade e apontam para possíveis contradições sociais, com os conhecimentos e práticas necessárias para a compreensão dos Temas Geradores e superação das situações-limites. Logo, a Rede Temática sintetiza as etapas desenvolvidas no processo de Investigação Temática possibilitando uma análise crítica da realidade social.

De acordo com Silva (2004), na Rede Temática também são evidenciadas as demandas e valores que emergem das contradições sociais, de forma a orientar a organização curricular com base nas concepções de educação de Paulo Freire. Estudos como os de Furlan (2015), Silva (2004) e Stuani (2016) apontam a importância de se considerar os valores no contexto da Abordagem Temática Freireana. Além disso, há pesquisas que têm investigado aspectos importantes sobre a utilização da Rede Temática, explorando aspectos como o processo de ensino e aprendizagem de química no contexto da organização curricular para turmas de EJA (Lambach, 2013); as contribuições da Rede Temática no desenvolvimento da cultura de participação (Milli et al., 2018a) e as potencialidades que a Rede Temática apresenta na elaboração de um projeto interdisciplinar baseado em uma perspectiva de Educação Popular (Silva, 2013). Contudo, é importante nesse processo de construção da Rede Temática, que é realizado em colaboração com os educadores, compreender a concepção desses sobre os valores envolvidos na elaboração de uma Rede Temática em processos formativos.

Portanto, buscamos responder as seguintes questões: Considerando a percepção de educadores da Educação Infantil, quais são os valores que permeiam a construção de uma Rede Temática? E qual a importância desses valores na organização curricular? Para Silva (2004, p. 84) “perseguir respostas a essas questões significa atuar voluntariosamente na superação de práticas e concepções que vêm se revelando como obstáculos à humanização desejada”, visto que o desvelamento da dimensão axiológica nos mecanismos utilizados nos sistemas educacionais pode revelar o caráter humanizador ou desumanizador desses sistemas.

No presente estudo, investigamos a compreensão de educadores acerca de valores presentes na construção colaborativa de uma Rede Temática. As informações analisadas foram obtidas durante um processo formativo para a obtenção de Temas Geradores realizado com educadoras de uma escola de Educação Infantil, localizada no bairro Iguape, no município de Ilhéus/BA. Tem-se como pressuposto que na construção de uma Rede Temática emerjam alguns valores que podem contribuir para o reconhecimento e fortalecimento do sistema de valores inerentes à cultura local, por meio de conteúdos significativos no currículo escolar. 


\section{A dimensão axiológica no Ensino de Ciências}

Quando se diz que algo possui algum sentido, significa que algo serve para a realização de um valor (Hessen, 1974). Assim, os valores se constituem enquanto qualidades, características ou estruturas que são atribuídas por alguém a um objeto, ação, situação etc. (Hessen, 1974). A área do saber que discute os valores é a axiologia, como indica a própria origem etimológica desta palavra, que vem do grego axio (valor) e logos (estudo) (Pedro, 2014). A axiologia é um termo amplo que está pautado em uma reflexão filosófica sobre os valores, isto é, na estrutura, características e teorias que envolvem os valores. A amplitude da axiologia funda-se no fato de que ela abrange a multiplicidade de valores existentes: éticos, morais, políticos, estéticos, ecológicos, vitais, espirituais, religiosos, econômicos etc. (Pedro, 2014).

Algumas pesquisas brasileiras, na área de Educação em Ciências, preocupamse com discussões que envolvem os valores e discutem aspectos como: a relação intrínseca entre a atividade científica e os valores, trazendo à tona a oposição entre as teorias positivistas e pós-positivistas (Cordeiro, 2016); a importância de se pensar o desenvolvimento moral dos alunos nas aulas de ciências, para que seja possível uma formação de natureza crítica (Razera, 2011); o papel dos valores nas tomadas de decisões tanto dos educandos quanto dos educadores (Dalri, 2010); as bases axiológicas inerentes aos currículos escolares (Furlan, 2015) e os dilemas entre a parcialidade e a imparcialidade da atividade científica (Raicik, \& Angotti, 2019; Santos, 2016).

A discussão dos valores no Ensino de Ciências pode revelar desde o porquê de alguns educandos não estabelecerem um compromisso com a aprendizagem escolar, a origem da indisciplina, a dificuldade em encontrar significado para os conceitos e conteúdos apresentados em sala de aula, até relações de opressão cultural (Lucas, 2014; Silva, 2004). Isso porque, como aponta Hessen (1974), toda ação humana está permeada de valores e toda a relação entre sujeito e objeto resulta em um juízo de valor. De acordo com Lucas e Passos (2015), há um consenso nas pesquisas em Educação em Ciências de que as discussões com perspectivas mais históricas e filosóficas, como é o caso da discussão da axiologia, desmitificam aspectos como a neutralidade e a imparcialidade que rodeiam as práticas científicas, estimula uma formação mais crítica, consciente e humana, e aponta para uma possibilidade de superação para a falta de significação dos conceitos e conteúdos trabalhados em sala de aula.

Para Moura (2011), de modo geral, o problema da educação está alicerçado na crise dos valores éticos e morais. Segundo o autor, o que decorre disso é uma crise de identidade, no sentido de que "no mundo do progresso tecnológico e da racionalização, não há espaço para a interioridade e os detentores do poderio industrial e científico é que informam ao homem moderno o que ele é ou, pelo menos, quem deveria ser" (Moura, 2011, p. 61). Um exemplo disso é o modo como a mídia é utilizada, em certos casos, para moldar as preferências, os comportamentos, as opiniões, ou seja, aqueles que detém o poder sobre a mídia, possuem também o poder sobre a disseminação em massa de determinados valores (Conti; Toral, \& Peres, 2008). 
O problema da educação é reflexo de uma crise ética, moral, ideológica, política e social que atinge a sociedade de modo geral (Moura, 2011). Nessa perspectiva, é preciso ter consciência de que "os valores são intrínsecos à educação, pelo que o problema educativo não é equacionável nem resolúvel sem incluir os valores. Assim, o estudo dos valores por parte dos educadores profissionais não é apenas necessário, é indispensável" (Patrício, 1993, p. 19).

Segundo Patrício (1993), toda ação pedagógica carrega em si valores e direcionamentos que promovem determinados valores em detrimento de outros. Logo, o processo educativo deve considerar os valores que são hierarquicamente superiores, uma vez que educar consiste em transformar o ser humano, o que implica incutir valores por meio do processo de ensino e aprendizagem. Não discutir os valores no âmbito educacional pode acarretar no niilismo, neutralismo, positivismo e o relativismo axiológico (Patrício, 1993). Em outras palavras, se o processo educativo não incluir a discussão dos valores no processo de desenvolvimento humano dos educandos, há a possibilidade de que esses educandos sejam cativados, em outros ambientes, por valores que não os permitam desenvolver uma consciência ético-crítica, libertadora e autônoma, o que reforça as relações de dominação, massificação, alienação e exclusão dos sujeitos em situação de opressão.

Portanto, pensar os valores e a concepção de educação antes de implementar as atividades didático-pedagógicas é imprescindível para que não ocorra a perpetuação das relações de opressão (Silva, 2004), uma vez que os educandos tendem a reproduzir o padrão valorativo existente nos ambientes que frequentam (Lucas, Passos, \& Arruda, 2016). Entendemos como necessária a preocupação com o padrão valorativo que se tem no ambiente escolar, já que a maioria das pessoas passa boa parte da vida nesses ambientes. Logo, se os educandos passam pelo processo de aprendizagem que está fundado em valores que nutrem uma relação opressora, então há uma grande probabilidade de que esses educandos cheguem a um perfil axiológico próximo ao dos seus professores, fazendo com que o ciclo continue (Lucas et al., 2016).

É de suma importância que os educadores compreendam que "qualquer reflexão ou proposição que façamos sobre a prática curricular envolve, implícita ou explicitamente, a análise dos objetivos dessa prática, das suas intenções e interesses, das escolhas realizadas a cada momento pedagógico, dos valores que balizam o fazer-educativo" (Silva, \& Pernambuco, 2014, p. 124). Uma reflexão axiológica, nesse contexto, evidencia sua importância ao indicar que nas bases dos sistemas educativos existem valores que sustentam os princípios norteadores desses sistemas. O que revela a impossibilidade de uma prática pedagógica neutra ou imparcial, uma vez que a ação que sustenta essa prática se orienta por interesses, vontades, intenções a fim de atingir determinados objetivos, que se caracterizam como um ideal educacional, amparado em valores que fundamentam tal idealização.

A discussão axiológica perpassa as diversas concepções de educação, como a humanista, tecnicista, tradicional, progressista etc. Independente da concepção 
de ensino e aprendizagem que se adote há sempre um propósito que estará fundado em um sistema de valores (Patrício, 1993). Por exemplo, na concepção tradicional ou "bancária" há a crença de que o processo de ensino e aprendizagem é imparcial, neutro e unilateral (Freire, 1987), valores comumente atribuídos à ciência (Lacey, 1998), que consequentemente refletem no modo como se ensina ciências. Nesse mesmo contexto, a Axiologia Educacional indica justamente o contrário, pois, como já foi dito, nenhuma ação humana está isenta de valores, isso inclui a atividade científica, práticas religiosas, ações políticas, a prática pedagógica etc. (Patrício, 1993).

Uma breve reflexão sobre a prática docente revela como o ato de educar está inevitavelmente permeado de valores. Por exemplo, um professor ao final de uma atividade didático-pedagógica pode hipoteticamente se questionar ou ser questionado: "de que maneira posso avaliar minha aula?". A depender do seu desempenho e dos parâmetros que utiliza para sua avaliação, a resposta pode variar dentre ruim, regular ou boa. Com isso, o professor estará atribuindo valor ao seu desempenho enquanto docente. Mesmo que ele defenda que é possível uma prática docente isenta de valores, ao apresentar o que seria uma aula ideal, uma boa atividade, boa condição de trabalho, de acordo com o seu ponto de vista, já estaria valorando, pois seria o tipo de aula que ele concebe como "boa" e essa qualidade encontra seu significado em um sistema de valores (Hessen, 1974).

Lucas (2014) argumenta que os valores necessitam ser pensados levando em conta a experiência de vida das pessoas, que no contexto da sala de aula pode evitar o conflito de valores. Esse entendimento, da importância dos valores para a realidade da sala de aula, revela que a axiologia possui uma dimensão prática, como destaca Patrício (1993) ao elaborar uma praxiologia dos valores:

Como Hessen, pensamos que há quatro grandes ordens de problemas axiológicos: a) a ontologia dos valores; b) a gnosiologia dos valores; c) a antropologia dos valores; d) a teologia dos valores. Contudo, a perspectiva da Axiologia Educacional revela a existência de mais uma ordem de problemas axiológicos dentro da própria Axiologia Geral: a praxiologia dos valores. (Patrício, 1993, p. 46).

O processo educativo se constitui como a realização da práxis axiológica. Com a Axiologia Educacional, Patrício (1993) possibilitou a superação das limitações da Axiologia Pura ou Fundamental, que não indica como os valores podem ser considerados no plano da materialidade, ou seja, como uma reflexão axiológica pode contribuir para a transformação da realidade dos sujeitos. A ampliação da dimensão axiológica para o domínio da prática, realizada por Patrício (1993), parte da síntese da relação de diversas teorias e vertentes axiológicas na história da filosofia.

Segundo Patrício (1993), os valores podem ser classificados como: práticos caracterizados como instrumentos para a realização de outros valores; hedonísticos - ligados às situações e/ou sensações que podem causar prazer; estéticos - valores relacionados à beleza, harmonia, fruição, criação e sensibilidade; lógicos - referem-se ao conhecimento, à busca pela verdade, à racionalidade; éticos - valores como bem, bom, 
correto, certo etc., que norteiam as atitudes, costumes e hábitos humanos; e os religiosos - que dizem respeito ao divino. Considerando que a filosofia patriciana contempla e supera algumas limitações de outros autores da axiologia, a exemplo de Hessen, adotamos a classificação indicada por Patrício (1993) para identificar os valores no processo de elaboração da Rede Temática realizado na Escola Padre Giuseppe Bonomi.

\section{Procedimentos metodológicos}

\section{A obtenção do Tema Gerador no processo formativo e a programação curricular}

O Grupo de Estudos sobre Abordagem Temática no Ensino de Ciências (GEATEC), vinculado à Universidade Estadual de Santa Cruz, vêm atuando em atividades de formação de professores da Educação Básica, em algumas escolas da região sul da Bahia. O objetivo do grupo consiste em desenvolver processos formativos de professores, com foco na Abordagem Temática Freireana (Delizoicov, Angotti, \& Pernambuco, 2011; Silva, 2004), em parceria com escolas e Secretarias Municipais e/ou Estaduais de Educação em diversos municípios da região sul da Bahia. Nesses processos formativos o grupo elabora e implementa, em conjunto com professores, propostas curriculares com base em Temas Geradores, acompanhados pela pesquisa.

Com isso, o presente estudo foi realizado durante um processo formativo de professores na Escola Padre Giuseppe Bonomi, localizada no Iguape, bairro industrial na periferia da zona norte da cidade de Ilhéus/BA, que é parte da comunidade católica Novo Céu, e não possui fins lucrativos ou vínculos governamentais. A instituição acolhe em média 70 crianças da faixa etária entre três e cinco anos de idade, nos turnos matutino e vespertino. Atualmente a escola só possui a modalidade da Educação Infantil, mas estão ocorrendo reformas a fim de implementar os Anos iniciais do Ensino Fundamental. O processo formativo foi realizado nesta escola pelo fato de uma das integrantes do GEATEC ser a coordenadora pedagógica da instituição referida. A coordenadora propôs um trabalho colaborativo para que fossem desenvolvidos os processos formativos com as educadoras que necessitavam de auxílio para a elaboração de atividades da área de Educação em Ciências, bem como a estruturação de um Projeto Político Pedagógico (PPP) da escola, para a futura implementação dos Anos iniciais do Ensino Fundamental, que foi sistematizado no estudo de Assunção (2019).

Para atender essas demandas da escola, o GEATEC realizou um processo formativo intitulado "A Abordagem Temática Freireana na elaboração do Projeto Político Pedagógico da Escola Padre Giuseppe Bonomi”, com duração de 40 horas, com oito educadoras da referida escola de Educação Infantil. Esse processo formativo, realizado no período de setembro a dezembro de 2017, em colaboração com o GEATEC, teve como finalidade a construção do PPP da escola (Assunção, 2019) mediante a Investigação Temática na comunidade do bairro Iguape, seguindo as etapas propostas por Sousa, Solino, Figueiredo e Gehlen (2014), quais sejam: 
1) Aproximações iniciais com a comunidade local e escolar - realizamos algumas visitas à comunidade, para a obtenção de informações acerca de problemas sociais que os moradores da comunidade vivenciam. Fizemos fotografias de vários pontos do bairro e conversamos informalmente com moradores e educadoras da escola. As informações foram codificadas em um vídeo;

2) Apresentação de possíveis situações-limites à comunidade local - no processo formativo com as educadoras apresentamos o vídeo para ser descodificado por meio de alguns questionamentos a respeito das imagens exibidas. Também realizamos discussões sobre as fotografias e as falas dos moradores para identificar alguns aspectos relacionados à compreensão das educadoras sobre problemas vivenciados no bairro, indicando as seguintes possíveis situações-limites: compreensão acrítica sobre a educação no bairro, acomodação e aceitação de problemas como a poluição e a violência, contradição entre o discurso e a prática ao admitirem a existência dos problemas e continuar agindo de modo a perpetuá-los, visão limitada do papel do mangue para a comunidade, dentre outras (Assunção, 2019).

3) Legitimação da hipótese - discutimos algumas questões com as educadoras e com moradores e representantes do poder público, por meio do processo de codificação e descodificação (Freire, 1987), em que foram legitimados os seguintes Temas Geradores: "As riquezas naturais do Iguape: entre o discurso e a prática, pois notamos que a situaçãolimite referente à esse Tema Gerador consistia na acriticidade, por parte dos moradores e das educadoras, sobre a devastação dos recursos naturais, como a poluição das águas e do manguezal que cerca o bairro; e o Tema "Comunidade, você conhece o seu bairro?", por representar situações-limites como: visão limitada em relação à violência no bairro, e em relação ao papel social das fábricas etc.;

4) Organização da programação curricular - a quarta etapa da Investigação Temática, denominada Redução Temática, centra-se na sistematização do material obtido na etapa da Descodificação, além da seleção dos conteúdos, conceitos e ações que propiciam a compreensão do Tema Gerador, auxiliando na organização da programação curricular (Delizoicov, 1982). No processo formativo realizado com as educadoras, essa etapa compreendeu um conjunto de atividades que envolveu a elaboração da: a) Rede Temática; b) o Ciclo Temático e c) as Unidades de Conhecimentos que integraram o currículo escolar, pautadas no Ensino de Ciências. Como o foco da presente pesquisa é a Rede Temática e sua dimensão axiológica, o próximo item explicita a sua construção no processo formativo.

\section{A construção coletiva da Rede Temática}

A organização curricular, partindo do processo de Redução Temática, está necessariamente ligada à proposta do desenvolvimento da reflexão crítica sobre os problemas presentes na realidade dos educandos (Delizoicov, 1991). Assim, o intuito dessa proposta é contribuir para formação de cidadãos atuantes na superação das contradições sociais, o que rompe com a lógica de que os conteúdos e conceitos devem 
ser aprendidos somente como uma formalidade ou imposição do sistema educacional vigente, em que o conhecimento escolar possui um fim em si mesmo (Silva, 2004). Para Delizoicov (1991), os conhecimentos universais, que precisam ser compreendidos pelos sujeitos imersos em contradições sociais, devem ser dinâmicos e se transformarem em instrumentos efetivos na compreensão do Tema Gerador. Como medida de superação desse tema, legitimado por educadores e especialistas, Silva (2004) apresenta uma estrutura, denominada Rede Temática (Figuras 1 e 2), constituída em duas partes: a primeira consiste no desvelamento da percepção da comunidade sobre a própria realidade, em que se sintetizam as contradições sociais e situações-limites; a segunda consiste na percepção das educadoras em relação aos problemas da comunidade, em que se propõe "as relações entre os elementos da organização social que os educadores envolvidos no projeto qualificam como as mais consistentes para analisar os problemas locais" (Silva, 2004, p. 252).

A parte superior ou topo da Rede (Figuras 1 e 2) também compreende elementos como: Situação-problema, que se refere à condição existencial do sujeito, o que indica uma situação-limite; Questão geradora, que indica as tensões entre os conhecimentos baseados nas vivências dos sujeitos e os conhecimentos necessários para a compreensão e superação das contradições sociais presentes na realidade desses sujeitos, evidenciando o que precisa ser superado por meio de um projeto pedagógico libertador; Contratema, que consiste no oposto dialético do Tema Gerador, isto é, a antítese do Tema Gerador, pois enquanto esse último norteia a programação curricular, o contratema representa uma "síntese analítica/propositiva, desveladora da realidade local que se pretende construir com os educandos, na perspectiva da intervenção na realidade imediata" (Silva, 2004, p. 229).

Na parte inferior - base da Rede - constam os diálogos com os sujeitos, em que se destacam as falas representativas dos moradores, que ajudam a direcionar a organização da programação escolar. A Figura 1 mostra os elementos que estruturam a Rede Temática:

De acordo com Silva (2004), os conteúdos e conceitos sistematizados, com o auxílio da Rede Temática, contribuem para a construção de um conhecimento significativo para os sujeitos que o constroem, propiciand o o "desvelamento dos conflitos como contradições sociais", pois tem o objetivo de estabelecer relações nos planos da micro e macro organização social. Essas relações estão inter-relacionadas às dimensões materiais, culturais e políticas (Silva, 2004), uma vez que nela são apontadas as visões da comunidade local e escolar.

A Rede Temática se caracteriza por apresentar uma síntese dos conflitos, tensões e relações que configuram a realidade da comunidade, possibilitando, ulteriormente, a elaboração de uma programação curricular que contemple conceitos, conteúdos e ações visando colaborar para a efetivação de uma educação libertadora (Silva, 2004). Portanto, nesse instrumento pedagógico são contempladas as diferentes concepções dos sujeitos envolvidos na construção da prática educativa, perpassando a programação curricular da escola. 


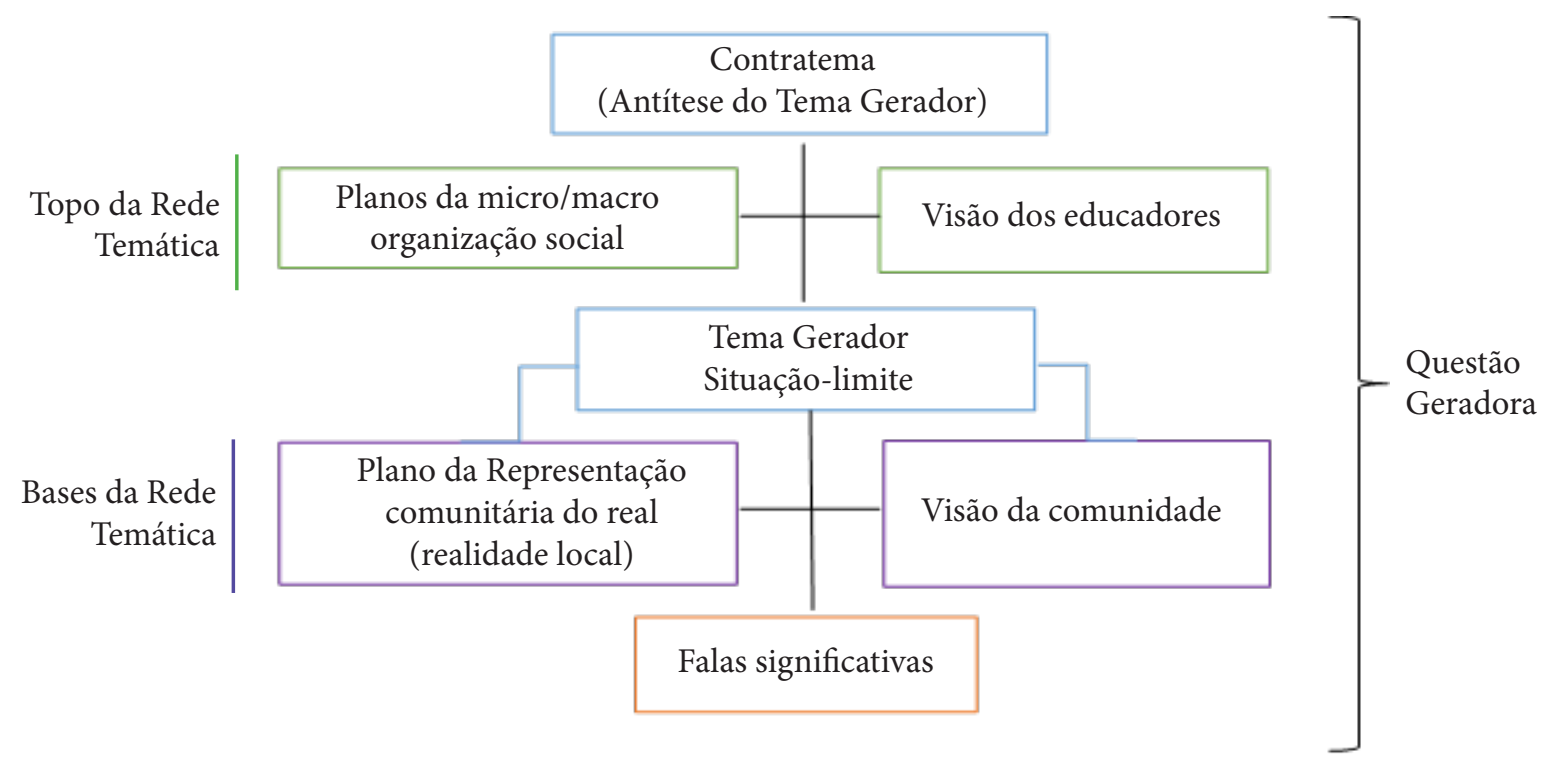

Figura 1. Síntese da Rede Temática baseada em Silva (2004)

Fonte: Fonseca (2017, p. 89).

No processo formativo realizado no bairro Iguape, a parte inferior da Rede Temática (Figura 2) apresenta diálogos destacando falas representativas que correspondem à compreensão que os moradores possuem da comunidade, o que propicia a identificação de situações-limites. Já a parte superior evidencia uma série de conceitos, conteúdos e ações (interligados por setas) que objetivam promover aos educandos uma compreensão crítica da realidade, no sentido de que possam superar as contradições sociais por meio de um currículo popular crítico (Silva, 2004). Assim, os conceitos, conteúdos e ações, evidenciados na parte superior da Rede (Figura 2), estão relacionados ao modo como as educadoras da Escola Padre Giuseppe Bonomi compreenderam os problemas vivenciados pela comunidade do Iguape, durante o processo de Investigação Temática (Sousa et al., 2014). No processo formativo realizado na escola, esse topo foi elaborado com base na colaboração entre as educadoras e o GEATEC no mesmo momento em que se elaborou a base.

A parte superior da Rede Temática concentra uma síntese da realidade, traduzida em conhecimentos e práticas que nortearão a elaboração das atividades didáticopedagógicas, posteriormente implementadas com os educandos. De acordo com Silva (2004, p. 252), nesse processo "parte-se então dos nexos pertinentes à localidade para uma dimensão micro, e desta para a representação macrossocial, buscando explicitar as relações socioculturais e socioeconômicas nos diferentes níveis a partir de sucessivas conexões". Assim, um currículo escolar em que o sujeito e sua cultura, negados historicamente, são norteadores para a construção do conhecimento, pressupõe-se uma dimensão axiológica, visto que o conhecimento se torna significativo ao sujeito à medida que o ajuda a compreender a realidade, o que fortalece o sistema de valores inerentes à cultura a qual pertence. 
Contratema: Ações Conscientes dos moradores do Iguape sobre os Recursos Naturais

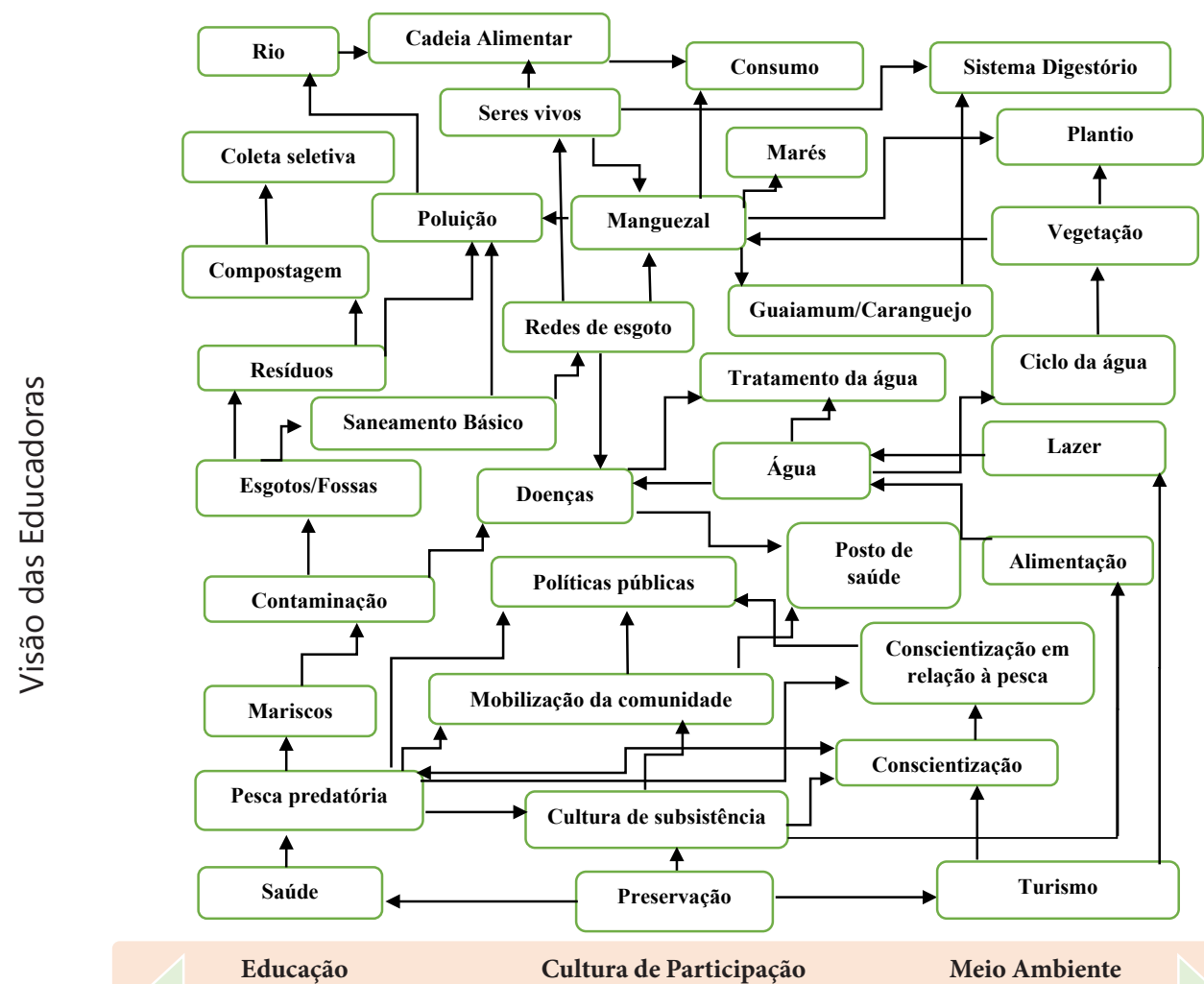

Questão Geradora: Água, fonte de vida; mangue, luta pela sobrevivência: o que fazer dessas riquezas naturais do nosso bairro?

Situação Problema: Falta de criticidade em relação às questões ambientais do bairro.

Tema Gerador 2: As riquezas naturais do Iguape: entre o discurso e a prática

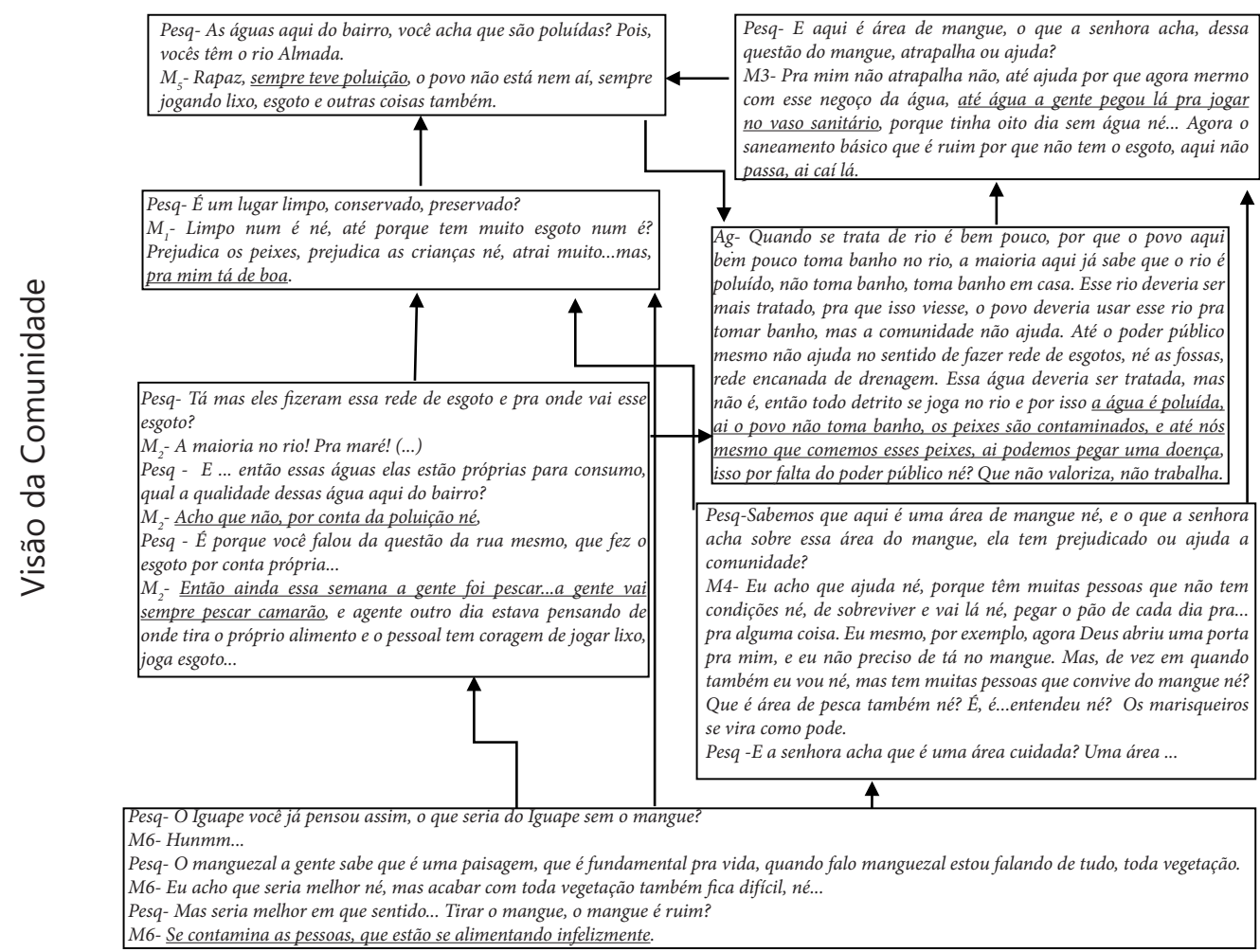

Figura 2. Rede Temática elaborada com base no Tema Gerador "As riquezas naturais do bairro Iguape: entre o discurso e a prática" (Assunção, 2019) 


\section{A construção das Unidades de Conhecimentos de Ciências}

Concluída a elaboração da Rede Temática, realizamos junto às educadoras a construção do Ciclo Temático (Milli et al., 2018a), que se caracteriza como um recurso metodológico utilizado nas pesquisas realizadas pelo GEATEC, que subsidia a sistematização das Unidades de Conhecimentos (Neres, 2016). A elaboração do Ciclo Temático (Figura 3) seguiu a mesma dinâmica de elaboração do topo da Rede Temática, pois o GEATEC e as educadoras empenharam-se cooperativamente na investigação das causas e consequências das situações-limites identificadas e sintetizadas no Tema Gerador "As riquezas naturais do bairro Iguape: entre o discurso e a prática", bem como as alternativas para superá-las.

O Ciclo Temático tem como objetivo caracterizar conteúdos, conceitos científicos e ações que são fundamentais para a compreensão do Tema Gerador, além de auxiliar na seleção de atividades e ações que viabilizam a superação de situações-limites, possibilitando uma transformação da realidade local (Milli et al., 2018a). Os elementos constituintes do Ciclo Temático, causas, consequências e alternativas, direcionaram a elaboração das três Unidades de Conhecimentos de Ciências, a saber: Poluição das Águas; Pesca e Manguezal. Portanto, as Unidades de Conhecimentos foram divididas em três, além de uma subunidade, como ilustra a Figura 4. É importante ressaltar que as Unidades, apresentadas na Figura 4, foram planejadas e organizadas dialeticamente com base nas causas, consequências e alternativas, uma vez que "é exatamente esta unidade dialética a que gera um atuar e um pensar certos na e sobre a realidade para transformála” (Freire, 1987, p. 14).

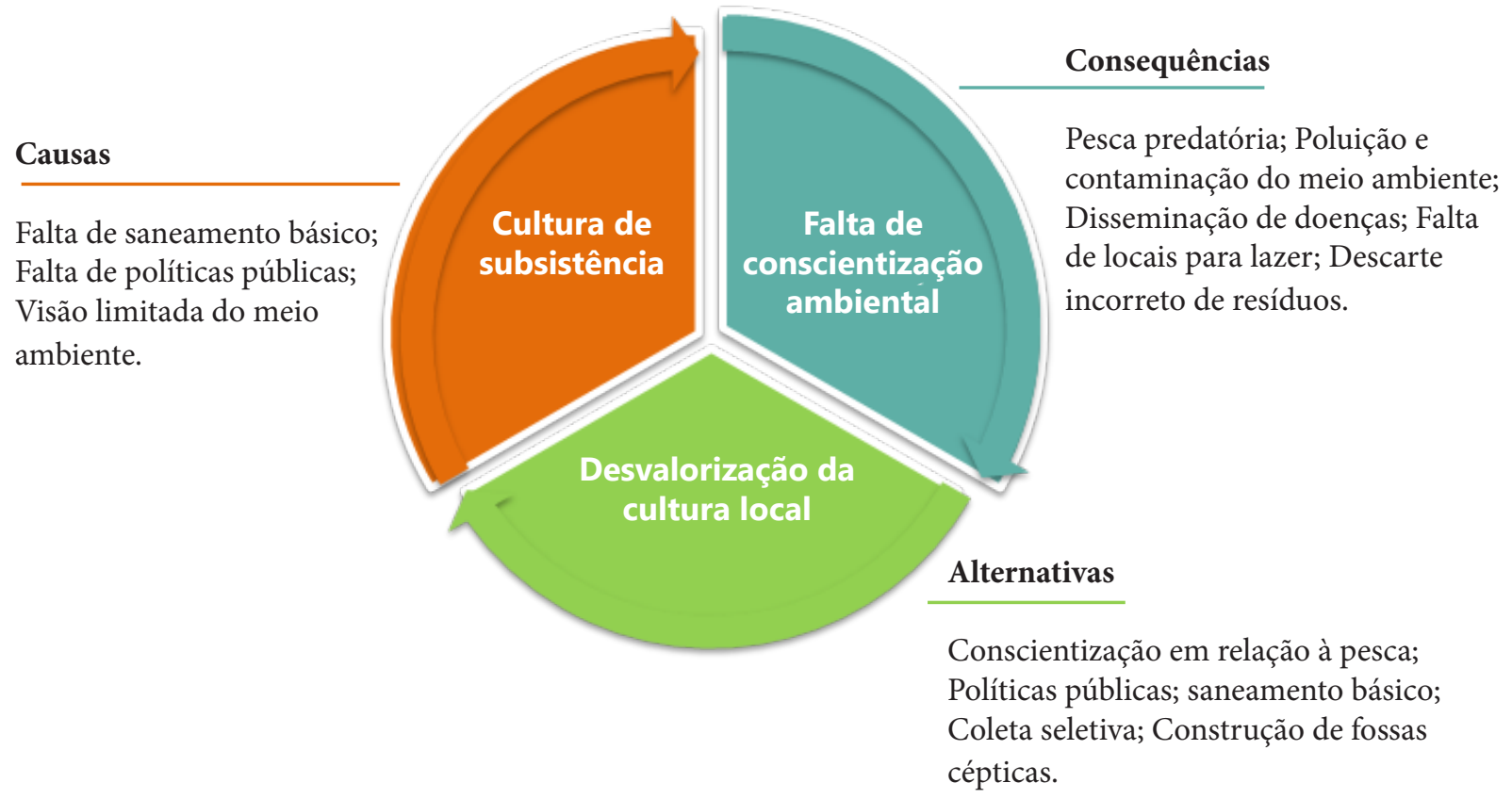

Figura 3. Ciclo Temático do Tema Gerador "As riquezas naturais do bairro Iguape: entre o discurso e a prática" (Assunção, 2019) 
Oito educadoras da Escola Padre Giuseppe Bonomi se envolveram voluntariamente no processo de Investigação Temática realizado na comunidade do Iguape, que consistiu em oito encontros com cinco horas cada. Desses oito encontros, dois foram reservados exclusivamente para a elaboração colaborativa, entre pesquisadores do GEATEC e as educadoras participantes, da Rede Temática, Ciclo Temático e Unidades de Conhecimentos. Conforme já destacado, a Rede proporciona um conhecimento significativo aos educandos por ter como ponto de partida os problemas e as necessidades oriundas da realidade do educando, o que indica a construção de um currículo que leva em consideração os valores inerentes à cultura local. Sendo assim, consideramos importante compreender, com base na percepção das educadoras, quais são os valores envolvidos na construção da Rede Temática.

Para tal, durante o processo formativo, foram realizadas entrevistas semiestruturadas, tendo como referência as questões explicitadas na Figura 5, com duas educadoras que participaram de todo o processo de Investigação Temática, inclusive trabalhando em colaboração e assiduamente na construção da Rede Temática. ${ }^{1}$ As demais educadoras, embora tenham se envolvido no processo, não participaram ininterruptamente dos encontros por motivos pessoais, por isso consideramos na análise as informações emitidas somente pelas duas educadoras assíduas no processo formativo.

As questões da Figura 5 foram direcionadas as duas educadoras e respondidas individualmente, a fim de que fosse possível compreender, de modo mais amplo, a percepção delas enquanto sujeitos ativos na construção da Rede Temática, isto é, as respostas dadas às questões poderiam apontar para as contribuições da Rede Temática no sentido epistemológico, praxiológico, gnosiológico, ontológico e axiológico. Sendo este último o foco do presente artigo.

1 Considerando que esta pesquisa envolve seres humanos, elaboramos um projeto que foi enviado e aprovado pelo Comitê de Ética e Pesquisa com Seres Humanos, sob o número CAAE: 90619518.8.0000.5526. Após a aprovação, respeitando os princípios éticos desse tipo de pesquisa, os sujeitos participantes foram apresentados aos procedimentos planejados para o desenvolvimento desta pesquisa e, ao concordarem com a proposta, assinaram o Termo de Consentimento Livre e Esclarecido (TCLE). 


\begin{tabular}{|c|c|c|c|}
\hline Unidade I & nidade II & \multicolumn{2}{|l|}{ Unidade III } \\
\hline Poluição das Águas & & \multicolumn{2}{|l|}{ Manguezal } \\
\hline \multirow[b]{2}{*}{$\begin{array}{l}\text { Resíduos domésticos no } \\
\text { manguezal e no rio; } \\
\text { Fossas; } \\
\text { Doenças: contaminação } \\
\text { dos animais e dos } \\
\text { alimentos; } \\
\text { Tratamento de água: } \\
\text { EMBASA/filtros de } \\
\text { água; } \\
\text { Rede de esgoto; } \\
\text { Políticas Públicas. }\end{array}$} & \multirow[b]{2}{*}{$\begin{array}{l}\text { Tipos de pesca; } \\
\text { Instrumentos de pesca; } \\
\text { Marés: Fases da Lua; } \\
\text { Tipos de peixes e mariscos; } \\
\text { Pesca predatória; } \\
\text { Aspectos históricos; } \\
\text { Preservação; } \\
\text { Conscientização; } \\
\text { Cultura de subsistência; } \\
\text { Fiscalização. }\end{array}$} & Subunidade & \\
\hline & & \multicolumn{2}{|c|}{$\begin{array}{l}\text { Diferença entre mangue e manguezal; } \\
\text { Poluição do manguezal; } \\
\text { Desvalorização da cultura local; } \\
\text { Descaso da população; } \\
\text { Resgate histórico das riquezas naturais } \\
\text { do bairro; } \\
\text { Preservação do manguezal; } \\
\text { Cultura de subsistência; } \\
\text { Importância econômica. }\end{array}$} \\
\hline \multicolumn{4}{|l|}{ Falas de moradores } \\
\hline $\begin{array}{l}\text { M1- Limpo num é né, } \\
\text { até porque tem muito } \\
\text { esgoto num é? Prejudica } \\
\text { os peixes, prejudica } \\
\text { as crianças né, atrai } \\
\text { muito..., mas, pra mim } \\
\text { tá de boa. } \\
\text { M3- Pra mim não } \\
\text { atrapalha não, até ajuda } \\
\text { por que agora mermo } \\
\text { com esse negoço da } \\
\text { água, até água agente } \\
\text { pegou lá pra jogar } \\
\text { no vaso sanitário, } \\
\text { porque tinha oito dia } \\
\text { sem água né...Agora } \\
\text { o saneamento básico } \\
\text { que é ruim porque } \\
\text { não tem o esgoto, aqui } \\
\text { não passa, aí caí lá (se } \\
\text { referindo ao mangue). }\end{array}$ & $\begin{array}{l}\text { M2- Então, ainda essa semana } \\
\text { a gente foi pescar. A gente } \\
\text { vai sempre pescar camarão, } \\
\text { e a gente outro dia estava } \\
\text { pensando: de onde tira o } \\
\text { próprio alimento e o pessoal } \\
\text { tem coragem de jogar lixo, } \\
\text { esgoto... } \\
\text { M4- [..] muitas pessoas que não } \\
\text { tem condições né, de sobreviver } \\
\text { e vai lá né, pegar o pão de cada } \\
\text { dia. Eu mesmo, por exemplo, } \\
\text { agora Deus abriu uma porta } \\
\text { pra mim, e eu não preciso de } \\
\text { tá no mangue. Mas, de vez em } \\
\text { quando também eu vou né, mas } \\
\text { tem muitas pessoas que convive } \\
\text { do mangue né? Que é área de } \\
\text { pesca também né? É. Entendeu } \\
\text { né? Os marisqueiros se vira } \\
\text { como pode (sic). }\end{array}$ & \multicolumn{2}{|c|}{$\begin{array}{l}\text { M6- Eu acho que seria melhor né, mas } \\
\text { acabar com toda vegetação também fica } \\
\text { difícil, né? } \\
\text { Pesq.: Mas seria melhor em que sentido? } \\
\text { Tirar o mangue? O mangue é ruim? } \\
\text { M6- Se contamina as pessoas, que estão } \\
\text { se alimentando infelizmente. } \\
\text { Ag- [..] a maioria aqui já sabe que o } \\
\text { rio é poluído, não toma banho. Esse } \\
\text { rio deveria ser mais tratado, mas a } \\
\text { comunidade não ajuda. Até o poder } \\
\text { público mesmo não ajuda no sentido } \\
\text { de fazer rede de esgotos, né as fossas, } \\
\text { rede encanada de drenagem. Essa água } \\
\text { deveria ser tratada, mas não é, então } \\
\text { todo detrito se joga no rio e por isso } \\
\underline{\text { a água é poluída, aí o povo não toma }} \\
\underline{\text { banho, os peixes são contaminados, e até }} \\
\underline{\text { nós mesmo que comemos esses peixes, }} \\
\underline{\text { aí podemos pegar uma doença, isso }} \\
\text { por falta do poder público né? Que não } \\
\text { valoriza, não trabalha. }\end{array}$} \\
\hline
\end{tabular}

Figura 4. Unidades e subunidade desenvolvidas no contexto do processo formativo da Escola Padre Giuseppe Bonomi (Assunção, 2019) 
Questões norteadoras da entrevista semiestruturada

1. Qual sua opinião sobre a Rede Temática enquanto instrumento de organização curricular?

2. Para você a Rede Temática ajuda na organização e elaboração das aulas? De que maneira?

3. A Rede temática contribuiu par a organização de conteúdos e conceitos da área de Ciências? De que forma?

Figura 5. Questões norteadoras da entrevista semiestruturada

Além disso, foram realizadas videogravações dos dois encontros para a construção da Rede Temática, em que posteriormente foram transcritos os diálogos entre as educadoras e os pesquisadores do GEATEC. A utilização deste instrumento justifica-se no fato de que permite a obtenção de informações para além do roteiro das perguntas nas entrevistas, possibilitando uma análise mais detalhada da dimensão axiológica nesse contexto. Essas informações foram analisadas por meio da Análise Textual Discursiva (ATD) que, de acordo Moraes e Galiazzi (2011), é um exercício cíclico de elaborar sentido, uma vez que um mesmo texto pode oferecer uma multiplicidade de significados. A ATD tem sido uma ferramenta importante na análise de informações e vem sendo muito utilizada na área de Educação em Ciências, especificamente em processos formativos freireanos como um procedimento de análise teórico-metodológica, pois auxilia no estudo interpretativo dos níveis de percepção que os sujeitos possuem sobre si mesmos e sobre sua realidade (Milli et al., 2018b).

Portanto, nesse processo é preciso delimitar o corpus, que são os textos que serão analisados. Neste estudo, o corpus foi construído a partir da transcrição das informações emitidas pelas duas educadoras que participaram assiduamente do processo formativo, tanto com base nos diálogos registrados em videogravações quanto nas entrevistas, em que a análise consistiu as seguintes etapas: a) Unitarização: originando as unidades de sentido com base nas falas das educadoras, obtidas nas entrevistas e nas videogravações, que apresentavam algum elemento axiológico na construção da Rede Temática; b) Categorização: em que se agruparam as unidades de significado de acordo as semelhanças semânticas, possibilitando a identificação das seguintes categorias a posteriori: i) Os valores na interação entre escola e comunidade: nesta categoria observamos aspectos que caracterizam a relação da comunidade escolar com a comunidade do Iguape. De acordo com Patrício (1993), a relação dos sujeitos entre si e com o mundo é o que fundamenta o processo de valoração, tanto no desenvolvimento de uma determinada cultura quanto no processo educativo. Portanto, tendo como base o caráter relacional da axiologia, o foco nesta categoria é investigar quais valores emergem das relações que as educadoras estabelecem com os moradores e com a realidade em si da comunidade do Iguape; ii) Os valores na programação curricular de ciências: esta categoria se estabeleceu com base no entendimento de que o processo educativo não é neutro. Como destaca Patrício (1993, p. 20), os valores são indissociáveis da educação, pois "a decisão humana de educar e ser educado só é inteligível à luz de um referencial axiológico". Nesse sentido, o foco nesta categoria é analisar quais valores são implicitamente considerados pelas educadoras na organização curricular de ciências que se pauta na compreensão e superação de 
problemas inerentes à realidade dos educandos; e c) A captação do novo emergente, em que houve a elaboração dos metatextos, que se originam das interpretações e descrições baseadas nas unidades de significado e nas categorias identificadas.

Tendo como base as informações obtidas por meio das entrevistas e das videogravações, organizamos as falas de maneira a garantir a privacidade dos sujeitos participantes, representando-as por meio da seguinte sequência alfanumérica: Falas das educadoras obtidas nas entrevistas - P1E, P2E; Falas obtidas nas videogravações - P1V, P2V.

Por tratar-se de uma análise que envolve juízos de valor emitidos por duas educadoras em relação aos aspectos da comunidade do Iguape e também sobre a organização curricular da Escola Padre Giuseppe Bonomi, entendemos que é necessário explicitar algumas características das educadoras P1 e P2 que participaram das ações: P1 tem 32 anos, é técnica em administração, cursa Pedagogia, atua na escola há quatro anos lecionando para turmas com crianças entre três e quatro anos; P2 tem 27 anos, é estudante de Engenharia Civil, atua na escola há três anos lecionando para turmas com crianças entre quatro e cinco anos. É importante ressaltar que ambas educadoras realizam esse trabalho voluntariamente e residem na comunidade em que a escola está inserida.

\section{Perspectivas axiológicas na construção colaborativa da Rede Temática}

\section{Os valores na interação entre escola e comunidade}

A Rede Temática se constitui em um mecanismo pedagógico que orientou a organização curricular da área de Ciências na Escola Padre Giuseppe Bonomi. Nesse sentido, objetivamos identificar os valores, com base na classificação dos valores organizada por Patrício (1993) por meio de uma Axiologia Educacional, presentes no processo de construção da Rede Temática desenvolvida nesse contexto. Além de evidenciar a importância de se discutir os valores na organização curricular da escola em questão, tendo como base os pressupostos político-pedagógicos freireanos e os princípios ético-críticos dusselianos. Destarte, constatamos a atribuição de valor por parte de P2:

Como se trata da Rede Temática, da relevância, da importância dela na organização curricular, a gente percebe que ela acaba se tornando valiosíssima. Ela nos traz a possibilidade de fazer uma leitura coletiva da realidade onde a escola está inserida, traz detalhadamente os discursos da comunidade relacionando determinados assuntos onde a gente pode construir um diálogo trazendo uma concepção tanto metodológica quanto epistemológica para que haja uma prática educativa efetiva. (P2E - grifo nosso).

$\mathrm{Na}$ fala de P2 é possível observar que o valor prático atribuído à Rede Temática tem relação com o diálogo estabelecido entre comunidade e escola, ou seja, o diálogo é o pressuposto necessário para que a realidade escolar e a realidade da comunidade 
estabeleçam uma relação dialética que "envolve a busca de contradições na realidade social; implica uma penetração além e abaixo das aparências superficiais" (Roberts, 2000, p. 36, tradução nossa). Para Freire (1987), o diálogo é o fundamento da intersubjetividade humana, o preceito para as relações históricas, sociais e culturais em que os sujeitos se reconhecem mutuamente, isto é, a condição imprescindível para o processo de humanização. Nesse sentido, o diálogo caracteriza-se como um valor prático, visto que é o meio para a realização de um propósito (Patrício, 1993), que nesse caso é a efetivação de uma educação libertadora.

Ao compreender que a escola necessita manter uma relação dialógica com a comunidade para que as contradições sociais sejam superadas por meio da educação, identificamos na fala de $\mathrm{P} 2$ o valor ético da humanização inerente à sua própria prática educativa, pois "a ação ética é inevitavelmente concreta. Pode concluirse que o trabalho educativo, compreendido nesta perspectiva, não pode desenvolver-se corretamente em enquadramentos utópicos e ucrónicos, tendo de ser implacavelmente situacional". (Patrício, 1993, p.141).

P2, ao assumir "uma leitura coletiva da realidade onde a escola está inserida" como ponto de partida para sua prática pedagógica, indica uma ação educativa de comprometimento ético e político com os educandos (Furlan, 2015). Isso fica mais evidente no excerto a seguir, em que P2 justifica o agrupamento de algumas falas significativas dos moradores a partir de uma situação-limite, durante o processo de construção da Rede do Tema Gerador "As riquezas naturais do bairro Iguape: entre o discurso e a prática".

"Visão limitada sobre o papel do mangue no bairro" (situação-limite). Muitas vezes as pessoas não sabem o real significado do mangue para a sua comunidade, com a visão limitada. (P2V).

$\mathrm{O}$ compromisso ético e político, atrelado à prática pedagógica, consiste em implementar uma concepção de educação que permita esses sujeitos compreenderem criticamente a própria realidade. A fala de $\mathrm{P} 2$, considerada no contexto do processo formativo, da elaboração do PPP, da Rede Temática, do Ciclo Temático, das Unidades de Conhecimentos de Ciências, indica que a concepção de educação que fundamenta a organização curricular da escola onde atua objetiva estimular a criticidade para que os educandos compreendam as contradições sociais presentes em sua realidade, possibilitando alternativas de superação da condição de oprimido, por meio de conhecimentos de ciências.

Outro aspecto a destacar nas falas das educadoras diz respeito à identificação dos valores práticos e éticos (Patrício, 1993) que fomentam uma relação humanizadora ou uma relação desumanizadora entre os sujeitos no processo educativo. Na fala de P1, observamos o seguinte:

O que há de inovador na Rede é o processo dialógico interativo, que visa fazer do indivíduo um ser melhor, mais participativo, lembrando que deve levar a uma ação 
transformadora, pois o pensar e o agir andam juntos para formar cidadãos que saibam ouvir. (P1E - Grifo nosso).

Notamos que P1 indica a interação e a dialogicidade como características da Rede Temática que integrada ao processo educativo, faz "do indivíduo um ser melhor", ou seja, oferece ao educando as condições para conscientização e superação da situação desumanizadora em que se encontra, tornando-se um Ser Mais (Freire, 1987). Percebemos, também, que P1 aponta para o desenvolvimento de uma consciência comunitária, que estimula o educando as práticas coletivas, o que caracteriza o processo educativo como humanizador, visto que a prática pedagógica e o currículo que guiam a formação desses educandos possuem um comprometimento ético com a comunidade e com os indivíduos que vivem nela (Dussel, 1977). Com isso, o sistema educacional:

Deixa de ser uma imposição domesticadora, formal, que educa amestrando corpos e mentes a interesses morais individualizados, comprometidos ontologicamente com os valores civilizacionais e colonizadores eurocêntricos, para tornar-se uma criação humana coletiva, que transforma a realidade em busca da autonomia com a superação das necessidades fundamentais de "produção, reprodução e desenvolvimento da vida humana - critério material universal da ética" (Silva, 2004, p. 84).

A fala de P1 consiste em uma valoração positiva (Lucas; Passos, 2015), pois julga que a Rede Temática contribui para uma formação que estimula a reflexão e a participação na transformação do mundo (Silva, 2004). Esse julgamento parte da percepção que P1 construiu com base na proposta de educação dialógico-problematizadora trabalhada durante o processo formativo, em que o currículo não é mais compreendido como uma mera soma de recortes da produção científica, mas sim "como um processo de apreensão crítica da realidade, em que as necessidades materiais para a sobrevivência humana em seus diferentes planos de existência orientam a visita criteriosa aos acervos epistemológicos específicos" (Silva, 2004, p. 84).

Nesse sentido, os valores que $\mathrm{P} 1$ atribui à Rede Temática são o diálogo, a interação e a participação, que são valores classificados como práticos, uma vez que direcionamse à realização de algo e situam-se no âmbito comunitário (Patrício, 1993). O diálogo, a interação e a participação, considerados como valores práticos, direcionam-se à realização de valores éticos como a coletividade, humanização e o comprometimento com o outro. Esses valores práticos e éticos, revelam uma dimensão sócio histórica, pois “o diálogo, ou, para ser mais preciso, o exercício do diálogo, tem um 'conteúdo', tem a exigência de superar a assimetria na dialética dominada pelo dominador" (Dussel, 2013, p. 319, tradução nossa). O diálogo, a interação, a participação, a coletividade, a humanização e o comprometimento com o outro são valores que fomentam a libertação dos oprimidos nas relações de opressão, visto que fundamenta uma concepção de educação "que apresenta intencionalidade política explícita de resistência às situações de dominação, procura contribuir com os movimentos socioculturais imbuídos em alterar a realidade sociocultural e econômica injusta, 
optando político-pedagogicamente pelos excluídos" (Silva, 2004, p. 71).

É possível notar a emissão de alguns juízos de valor das educadoras em relação à Rede Temática, em que identificamos valores práticos como interação e envolvimento, tendo como base os pressupostos de Patrício (1993), como consta no extrato:

Primeiro ela (a Rede Temática) melhora, causa melhor interação entre o professor e a comunidade na hora de selecionar os conteúdos. Causa também o envolvimento dos professores nesse processo, de modo que ele passa a perceber quais são os problemas da comunidade, identifica, reconhece e, a partir dali, ele vai começar a trabalhar, a preparar a aula, partindo desse pressuposto. (P2E - Grifos nossos).

Observamos que P2 utiliza expressões como 'melhora' e 'melhor' se referindo às contribuições da Rede Temática em sua prática pedagógica. Isso denota um juízo de valor positivo, pois quando se reconhece algo como valioso, atribui-se um valor cuja polaridade é positiva, isto é, um juízo de valor positivo corresponde à atribuição de valor a determinado objeto cuja qualidade diz respeito à agradabilidade, utilidade, prazer, admiração etc. (Hessen, 1974). Em outros casos, quando há a depreciação de algo, emitese um juízo de valor negativo, ou seja, um 'desvalor' (Hessen, 1974). No caso da fala emitida por P2, o juízo de valor positivo está fundado em elementos como a interação entre professor e comunidade e envolvimento do professor no processo educativo. Destacamos, também, que os valores práticos como a interação e o envolvimento, mencionados por P2, servem como meio para a realização de um valor epistemológico, que é a construção de um conhecimento significativo aos educandos a partir da percepção dos problemas locais. Segundo Patrício (1993), os valores epistemológicos são entendidos como valores lógicos, pois estão relacionados ao desenvolvimento do conhecimento.

Quanto à concepção de $\mathrm{P} 1$, a valoração atribuída à Rede Temática se estabeleceu da seguinte maneira:

Como educadora eu acho importante aderir a Rede Temática à prática pedagógica, porque a partir daquela realidade local da escola, da comunidade, o aluno vai se sentir presente, pertencente daquilo que vai ser exposto na sala de aula. Ele vai ver que o que está sendo tratado em sala de aula não é algo que está distante dele, pelo contrário, é algo que está muito próximo, que está inserido na vida dele. (P1E).

P1 destaca a importância da Rede Temática, pois auxilia na elaboração de um currículo que possibilita a conscientização dos educandos em relação ao contexto ao qual pertencem, relacionando o conhecimento construído na escola com a realidade cotidiana deles, evidenciando que a comunidade possui um valor para seus moradores e para a escola. Nesse sentido, a conscientização caracteriza-se como um valor prático, pois entendendo-a como um pressuposto "que prepara os homens, no plano da ação, para a luta contra os obstáculos à sua humanização" (Freire, 1987, p. 65), contempla ação e reflexão e orienta-se à transformação da realidade. A educadora reforça essa ideia em outro trecho: 
Essa conscientização não existe porque eles pensam 'já está poluído, o esgoto já cai lá, então se eu jogar mais uma sacola de lixo não vai fazer diferença'. Sendo que um plástico leva quanto tempo para se decompor?! (P1V).

P1 mais uma vez chama a atenção para o fato da falta de conscientização ambiental, o que revela uma ausência de atribuição de valores ligados à conservação do meio ambiente (Sena, 2010), indicando uma visão limitada por parte dos moradores em relação aos problemas presentes na comunidade. Desse modo, um currículo que traz para a escola as discussões referentes aos problemas da comunidade, exprime sua importância quando apresenta a possibilidade de transcender uma visão limitada e acrítica do mundo, propiciando uma postura ativa e efetiva na elaboração de alternativas para a superação dos problemas da comunidade.

Portanto, as educadoras P1 e P2 enunciam juízos valorativos sobre a Rede Temática tendo como base o comprometimento crítico, ético e político inerente a uma prática pedagógica que respeita os valores, crenças e a história da comunidade local, já que "conceber a reorientação curricular como uma prática ética significa assumir o processo de construção, sistematização e implementação da prática pedagógica da escola pública como um processo participativo, crítico e formador" (Silva, 2004, p. 71).

A partir da percepção de P1 e P2 sobre a Rede Temática compreendemos que este instrumento pedagógico contempla um conjunto de elementos culturais e políticos, e necessita da visão dos sujeitos sobre seu contexto, a partir de falas significativas que representam a comunidade (Fonseca, 2017; Silva, 2004), para que haja de fato um diálogo com a escola. Nesse sentido, o ambiente educacional se configura como um dos espaços mais importantes em que os educandos são incutidos de valores, por isso uma prática pedagógica educativo-crítica está alicerçada em valores éticos e políticos que promovem o reconhecimento dos valores da cultura local (Freire, 1987) e é essa a principal característica da dimensão axiológica na relação dialógica entre comunidade e escola.

Em síntese, constatamos que no processo de elaboração da Rede Temática as educadoras P1 e P2 indicaram alguns valores que são importantes para a Educação em Ciências na etapa da Educação Infantil, quais sejam: valores práticos, como o diálogo, interação, participação, envolvimento e a conscientização; valores éticos, como a coletividade, humanização e o comprometimento com o outro; e o valor lógico relacionado ao desenvolvimento de um conhecimento significativo aos educandos.

\section{Os valores na programação curricular de ciências}

É importante ressaltar que neste estudo a elaboração das Unidades de Conhecimentos, oriundas da Rede Temática, desenvolveu-se para o contexto da Educação em Ciências para crianças da Educação Infantil. Portanto, consideramos imprescindível a discussão sobre a percepção das educadoras em relação aos valores envolvidos no processo de ensino e aprendizagem das ciências, uma vez que alguns estudos têm evidenciado a importância da dimensão axiológica nessa área de conhecimento (Bezerra, 
\& Amaral, 2019; Dalri, 2010; Furlan, 2015; Lucas, 2014; Moura, 2011; Razera, 2011).

Nessa perspectiva, P2 apresenta sua percepção acerca do processo de ensino e aprendizagem das ciências, pautado na Abordagem Temática Freireana, destacando o seguinte:

(A Rede Temática) revela a capacidade de aproximar o contexto com o conhecimento científico. Aí a rede acaba fazendo o que? Estabelecendo uma ponte entre essas visões da comunidade e do professor na construção desse saber. É no meio do diálogo que encontram os conteúdos de cada área do conhecimento, que possam ser selecionados e aplicados na hora de preparar as aulas. (P2E).

P2 enfatiza que os conhecimentos construídos na escola, ou seja, os conhecimentos científicos, necessitam ter uma relação intrínseca com o mundo dos educandos. A relação entre contexto social e conhecimento científico, salientada por P2, caracterizase como um valor lógico da Rede Temática à medida que essa relação viabiliza um conhecimento sobre a realidade (Patrício, 1993). Considerando que a Rede Temática viabiliza uma organização curricular pautada em conhecimentos que propiciam uma compreensão crítica sobre os problemas existentes na realidade, entendemos que a criticidade se constitui enquanto um valor lógico, no sentido epistemológico, inerente à Rede Temática.

Além disso, P2 indica que a Rede Temática abrange tanto a visão da comunidade quanto do educador. Ao considerar ambas visões de mundo, P2 evidencia que a Rede Temática auxilia na viabilização de uma prática educativa que pauta-se no compromisso com outro, respeitando as diversas visões de mundo, caracterizando-se como um valor ético, visto que "no cerne da relação ética se encontra a responsabilidade pelo outro". (Patrício, 1993, p. 158). Essa responsabilidade revela-se na prática pedagógica do educador que considera a realidade do educando como o pressuposto para a construção do conhecimento, ou seja, no desenvolvimento de um conhecimento crítico os valores lógicos e éticos são indissociáveis.

Essa relação entre a realidade da comunidade e o desenvolvimento do conhecimento só é possível quando o processo de ensino e aprendizagem envolve valores cognitivos e afetivos (Dalri, 2010), isto é, quando a construção do conhecimento parte de problemas presentes na realidade a qual se pretende compreender criticamente, pois são os sujeitos envoltos nessas situações problemáticas que vão revelar "visões impregnadas de anseios, de dúvidas, de esperanças ou desesperanças que implicitam temas significativos, à base dos quais se constituirá o conteúdo programático da educação" (Freire, 1987, p. 48). A fala de P2 pressupõe que o ensino e a aprendizagem, pautados na Abordagem Temática Freireana, estão fundamentados na relação dialógica entre a sabedoria popular e o conhecimento científico, o que possibilita a elaboração de atividades pautadas na dialogicidade.

Do mesmo modo, observamos na fala de P1 um destaque em relação à construção do conhecimento com base na realidade do educando:

Então vai ser muito mais prazeroso muito mais gostoso, dele falar daquilo que ele vive 
[...] Volto a dizer, do que ele buscar conceitos em coisas que traz em livros e tal [...] Então aqueles conhecimentos que ele vai trazer, aquela bagagem que ele traz para sala de aula, junto com os conhecimentos científicos do professor, vai trazer um bom resultado principalmente no processo de aprendizagem do educando. (P1E - Grifo nosso).

Na fala de P1, notamos por meio dos termos "prazeroso" e "gostoso" a atribuição de valores hedonísticos, que são valores relacionados ao prazer. Como destaca Patrício (1993, p. 110), “os valores hedonísticos não aparecem autonomamente na generalidade das classificações axiológicas", pois eles são causados por outros valores ou situações. Nesse caso, os valores atribuídos por P1 decorrem de valores lógicos, pois o prazer a que se refere advém da construção de conhecimentos significativos aos educandos.

Ressaltamos que os valores lógicos revelam-se tanto quando o educando apresenta um conhecimento baseado em suas vivências como quando o educador promove o conhecimento científico, desde que haja uma relação horizontal, em razão de que os valores lógicos se direcionam à construção do conhecimento que busca a verdade sobre a realidade. Portanto, "não deve nunca o educador comportar-se como se fosse uma autoridade maior que a da verdade propriamente dita" (Patrício, 1993, p. 138).

Em um contexto de sala de aula, de acordo com P1, os conhecimentos do educador e os saberes do educando se relacionam de maneira dialógica resultando na construção de um conhecimento significativo. Assim, uma atividade que esteja fundamentada na dialogicidade, que contemple a multiplicidade de saberes, é apontada por P1 como algo que traz "um bom resultado", ou seja, é valorado positivamente por apresentar significado tanto para o educando, quanto para o educador.

De acordo com Dalri (2010), a construção desses conhecimentos significativos não está relacionada somente com a dimensão cognitiva, pois partir de problemas da realidade do educando envolve a compreensão dos processos de representação simbólica da realidade. Esse processo de representação realiza-se mediante as relações que o indivíduo estabelece com o mundo, resultando em um processo de valoração, ou seja, "aquilo que possui para nós um valor é objeto de nossa preferência ou escolha; o que também tem significado para nós" (Dalri, 2010, p. 91). Em outras palavras, os elementos pertencentes ao cotidiano do educando possuem valor para ele, pois sua história se constituiu com base em sua relação com esses elementos. O sistema educativo que leva isso em consideração propicia uma aprendizagem que passa a ter valor afetivo e cognitivo para o educando.

Nesse sentido, justifica-se a importância de uma reflexão axiológica sobre os princípios basilares dos sistemas educacionais, já que a prática pedagógica, os conteúdos escolares, os métodos avaliativos e o currículo possuem intrinsecamente uma dimensão ética, moral, política, social e cultural que podem estar firmados em modelos de perpetuação das relações de exclusão e dominação (Silva, 2004). Nesse contexto, o processo de Investigação Temática apresenta-se como um aporte teórico-metodológico que contempla o sistema de valores da cultura local, estabelecendo uma relação dialógica entre escola e comunidade, revelando valores que foram caracterizados e classificados 
com base na Axiologia Educacional patriciana: práticos, como interação, envolvimento, participação, conscientização e diálogo; éticos, como a coletividade, humanização, comprometimento com o outro, responsabilidade mútua entre os sujeitos e respeito pelas diferentes visões de mundo; lógicos, como conhecimentos significativos e a criticidade; e hedonístico, como o prazer decorrente dos conhecimentos significativos.

Durante a etapa da Redução Temática, em que são selecionados conceitos, conteúdos e ações para compreensão do Tema Gerador, que nesse contexto resultou nas Unidades de Conhecimentos de Ciências, P2 destaca:

Aqui (base da Rede Temática) já entra a parte onde eles (moradores) falam que precisam do mangue, que o mangue é importante pra comunidade, pra pesca, pra sobreviver da venda do peixe... pra ganhar o pão de cada dia, como eles falam (P2V).

P2 se refere à seleção das falas dos moradores, obtidas durante o processo de Investigação Temática, que compuseram a base da Rede Temática. O próprio ato de escolher uma fala, em detrimento de outras, já denota uma relação axiológica do sujeito que escolhe com o objeto escolhido, pois toda escolha pressupõe uma intenção, que se apoia em um valor (Hessen, 1974, p. 40). Portanto, toda valoração se fundamenta em um 'porque' e, nesse caso, P2 justifica sua escolha no fato de que era preciso associar características da realidade da comunidade, na qual a escola está inserida, com os conteúdos que possibilitassem um ensino de ciências voltado para a compreensão crítica dessa realidade.

A fala de P2 revela seu entendimento sobre como os moradores compreendem aspectos próprios da comunidade em que vivem, evidenciando uma relação valorativo entre sujeito (morador) e objeto (mangue). Por exemplo: os termos 'precisam' e 'importante' (valores de utilidade) ${ }^{2}$ são direcionados ao mangue (objeto valorado), em seguida justifica-se a valoração quando os termos 'pesca', 'venda' e 'ganhar' indicam a atribuição de valor econômico ao mangue. Nesse caso, as falas dos moradores apontadas por P2, que compuseram a base da Rede Temática, são relevantes porque mostram como esses sujeitos possuem uma visão axiologicamente limitada sobre os recursos naturais presentes na comunidade, uma vez que somente o valor de utilidade econômica é identificado quando o mangue é mencionado, ou seja, são falas que expressam uma situação-limite.

Tendo como base as falas significativas dos moradores, obtidas durante a Investigação Temática, as educadoras, em cooperação com os pesquisadores do GEATEC, elaboraram as Unidades de Conhecimentos, que tiveram por objetivo fomentar atividades para ampliar os conhecimentos das crianças sobre o ecossistema manguezal. Nessa perspectiva, revela-se a importância de uma Axiologia Educacional, visto que o processo educativo que considera os valores práticos, éticos, estéticos, hedonísticos e lógicos pode contribuir para a superação de situações-limites. As complexidades da

2 Segundo Hessen (1974), os valores de utilidade estão relacionados à satisfação das necessidades humanas, por exemplo: o alimento possui um valor de utilidade, pois serve para saciar a fome. 
relação entre o homem, a sociedade e a natureza compreendem essa multiplicidade de valores, pois são imprescindíveis na formação da consciência ecológica sobre a dependência humana dos recursos naturais, da consciência cultural sobre como aquele ecossistema influenciou na cultura local, sendo um aspecto determinante na história da comunidade (Sena, 2010).

É nesse momento que o conhecimento científico e os saberes da experiência ajudam a evidenciar a importância do mangue de maneira mais ampla, sendo elementos fundamentais em um sistema educativo que visa a superação de situaçõeslimites. Essa relação dialógica com os sujeitos da comunidade convém "para que o seu conhecimento experiencial em torno da realidade, fecundado pelo conhecimento crítico da liderança, se vá transformando em razão da realidade" (Freire, 1987, p. 76), uma vez que o processo valorativo é o ensejo para a construção de novos conhecimentos e para a prática social (Mafra, 2007).

As educadoras, ao selecionarem as falas da comunidade para compor a base da Rede Temática (Figura 2), começaram a identificar as situações-limites 3 , para que fosse possível visualizar o ponto de partida material, analítico, econômico e político para a elaboração de um currículo pautado na concepção freireana de educação libertadora (Dussel, 2013). Desse modo, a elaboração das Unidades de Conhecimentos de Ciências possibilitou o planejamento e implementação de atividades que apresentassem, em alguma medida, alternativas de superação as contradições sociais identificadas.

No processo de construção do topo da Rede Temática (Figura 2) foram sistematizados diversos conhecimentos e ações necessários para a compreensão do Tema Gerador e norteamento das práticas que visam à superação das situações-limites. Ao serem questionadas sobre o que deveria constar nas Unidades de Conhecimentos, que envolvendo a área de ciências, para se trabalhar aspectos relacionados às situaçõeslimites identificadas, as educadoras responderam:

A importância do mangue para comunidade. (P1V).

A gente podia trabalhar os tipos de peixes presentes no rio aqui (referindo-se ao rio que passa pelo bairro). (P2V).

$\mathrm{Na}$ verdade, a gente poderia trabalhar os seres vivos, porque quando fala aqui (se referindo às falas dos moradores) sobre poluição, envolve os animais. (P1V).

As educadoras P1 e P2 evidenciaram conhecimentos que possuíam um caráter transversal, ou seja, as unidades possibilitariam atividades que englobassem o ensino e a aprendizagem de características culturais, históricas e científicas sobre a relação da comunidade com manguezal. Mas, como já foi dito, o foco inicial foi o ensino de ciências

3 Como explicitado no tópico "A obtenção do Tema Gerador no processo formativo e a programação curricular" deste artigo, as situações-limites identificadas por meio do processo de Investigação Temática na comunidade do Iguape, são: falta de criticidade na compreensão sobre a educação no bairro; naturalização de problemas como a violência e a poluição; prática incoerente com o discurso, visto que admitem a existência de alguns problemas, porém continuam agindo de modo a perpetuá-los; visão limitada do papel do mangue para a comunidade. 
e as educadoras podem ampliar essas Unidades de Conhecimentos para outras áreas. Nesse processo de elaboração das Unidades de Conhecimentos, a educadora P1 apresenta uma síntese que exemplifica uma das situações-limites identificada, a qual considera importante a ser trabalhada com os educandos:

Eu acho a parte do caranguejo, porque sempre ficam proibindo a caça de caranguejo/ guaiamum. Quando trabalharmos com seres vivos, a gente vai ter que falar da conscientização. Quando for falar dos animais do mangue, o animal aqui que eu acho que é mais tirado do mangue é guaiamum. Pelo fato de eles \{comunidade\} terem no quintal de suas casas. Daí, eles pegam tudo. Não olham se têm fêmeas ou não, pegam tudo [...] Então eu acho que o guaiamum e o caranguejo são os mais 'gritantes'. (P1V Grifo nosso).

Com base no relato sobre o período de defeso apontado por P1, e em outras falas significativas dos moradores da comunidade (Figura 4), foi possível sistematizar os conteúdos de uma das Unidades de Conhecimentos, pois o período de defeso, época em que a pesca é proibida por conta da reprodução dos animais, exige um conhecimento que explique a importância do controle da população de animais, tanto para o equilíbrio ambiental quanto para subsistência dos pescadores. Foi essa fala de P1 que contribuiu para a sistematização da Unidade II, denominada de Pesca (Figura 4), com os seguintes conhecimentos: Tipos de pesca; Instrumentos de Pesca; Marés e fases da lua; Tipos de peixes e mariscos; Pesca predatória; Aspectos históricos; Preservação; Conscientização; Cultura de subsistência; e Fiscalização.

Embora esses aspectos da Unidade II estejam direcionados para o ensino de Ciência, a dimensão axiológica não se desvincula deles (Patrício, 1993). Isso porque o processo de aprendizagem sobre os elementos que compõem o mangue envolve também um processo de valoração desses elementos, no sentido de que quando se reconhece a importância de algo, como os animais do mangue, por exemplo, atribui-se valor (Hessen, 1974). O próprio ato de se conscientizar, que consiste em um processo de desvelamento crítico da realidade (Freire, 1987), indica o reconhecimento de valores e desvalores como bom e ruim, justiça e injustiça, liberdade e opressão, autonomia e submissão etc. Isso quer dizer que o trabalho com os conhecimentos que auxiliam no desenvolvimento da conscientização ambiental fundamenta-se em conhecimentos científicos que possibilitam a ampliação dos valores atribuídos aos objetos estudados (Sena, 2010).

A lógica de sistematização e organização dos conteúdos das demais unidades foi a mesma utilizada na Unidade II. Nas falas a seguir, destacamos outras situações-limites identificadas pelas educadoras, como a acomodação com o problema da poluição e a prática incoerente com o discurso, justificando a necessidade de se construir as outras unidades, para que fosse possível desenvolver atividades com outros conteúdos (além dos conteúdos sistematizados na Unidade II) que visassem à superação dessas situaçõeslimites. 
Aqui tem poluição da água e poluição do mangue. Então assim, poluindo o mangue e o rio, o quê que causa? (P1V).

Tem falas de moradores que mostram que sabem e ainda assim pescam e muitas vezes esses peixes podem estar até doentes. (P2V).

P1 explicita a importância de se estudar as causas da poluição, que pode ser entendida de duas maneiras: 1) o descarte incorreto dos resíduos e a falta de saneamento básico, por exemplo, são causas mais 'visíveis' numa análise mais pragmática; 2) a falta de conscientização, a falta de um sentimento de pertencimento, de apatia social, histórica e cultural revelam causas mais profundas, que necessitam de uma análise mais reflexiva, visto que fazem parte de uma construção histórico-cultural (Gadotti, 2007; Scocuglia, 2008). Assim, os valores, envolvidos na construção das Unidades de Conhecimentos de Ciências, evidenciam-se no momento em que se investigam as causas mais originárias, por exemplo: o que as pessoas da comunidade sabem sobre poluição? O que poderia propiciar a conscientização sobre a importância da conservação do meio ambiente? Como o descarte do esgoto no mangue é visto pela comunidade? Qual a visão que os moradores possuem sobre o mangue? Dentre outras questões que revelam como os problemas identificados na comunidade apontam para uma causa de caráter estrutural, que em longo prazo influencia no processo de valoração dos moradores em relação aos elementos que constituem o bairro (Moura, 2011). Com isso, a percepção das educadoras sobre as causas histórico-culturais da poluição na comunidade revela o desvalor que os moradores atribuem ao mangue, pois agem de forma acrítica em relação à preservação do ecossistema do qual dependem economicamente e ecologicamente, ou seja, a desvalorização dos recursos naturais que o bairro possui está diretamente ligada a uma visão acrítica da própria realidade.

A educadora P2 apresenta essa acriticidade ao afirmar que alguns moradores até sabem que em determinados períodos é proibido pescar, que em alguns lugares a pesca não é aconselhável devido à poluição, mas mesmo assim fazem. As educadoras entendem que há indicativos de que os moradores dessa comunidade possuem uma compreensão limitada da própria condição existencial, no sentido de que não conseguem conceber a realidade de maneira crítica (Freire, 1987). A consciência crítica é o nível em que os sujeitos conseguem compreender que sua relação com o mundo se fundamenta em um sistema de valores, que está constantemente sendo modificado, e essa compreensão permite ao sujeito uma consciência ético-crítico de responsabilidade mútua com o outro e com o mundo (Dussel, 2013).

As educadoras e os pesquisadores do GEATEC elaboraram a Unidade I (Figura 4), intitulada de Poluição das águas, que tem como conhecimentos: Resíduos domésticos no manguezal e no rio; Fossas; Doenças: contaminação dos animais e dos alimentos; Tratamento de água: EMBASA/filtros de água; Rede de esgoto. Já a Unidade de Conhecimentos III, denominada Manguezal (Figura 4), consistiu nos seguintes conteúdos: Diferença entre mangue e manguezal; Poluição do mangue; Desvalorização da cultura local; Descaso da população; Resgate histórico das riquezas naturais do bairro; Preservação do manguezal; 
Cultura de subsistência; Importância econômica. Além disso, elaboramos uma subunidade para se trabalhar conhecimentos importantes para a compreensão do problema da poluição no manguezal, como: Ecossistemas e biodiversidade.

Todos os conhecimentos e ações que compõem as Unidades de Conhecimentos de Ciências estão interligados entre si, o que evidencia o caráter processual e gradativo de um sistema educativo que segue os pressupostos freireanos. Tais conteúdos foram selecionados em função da necessidade da compreensão crítica e da superação de problemas existentes na comunidade do Iguape. Esses problemas foram identificados pelas educadoras ao analisarem algumas falas que revelaram as visões limitadas de alguns moradores em relação aos recursos naturais da comunidade, salientando a necessidade da inserção de pressupostos axiológicos para a identificação de contradições sociais e na superação delas. Com base na organização curricular da Escola Padre Giuseppe Bonomi, que pautou-se na Abordagem Temática Freireana, entendemos que há indicativos quanto à necessidade de contemplar além das dimensões epistemológica, ontológica, gnosiológica e praxiológica (Stuani, 2016), a dimensão axiológica, visto que alguns valores, ou a ausência deles, podem auxiliar na identificação de situações-limites.

\section{Algumas considerações}

Nesse processo de formação de professores, pautado na perspectiva freireana, as educadoras associaram a utilização da Rede Temática ao comprometimento ético e político que rege suas práticas pedagógicas, apontando para valores que emergiram da relação dialógica entre comunidade e escola, tais como: valores práticos - diálogo, interação, participação, envolvimento e conscientização; valores éticos - coletividade, humanização e o comprometimento com o outro; valor lógico - conhecimento significativo. No contexto da Educação em Ciências, esses valores são elementos que também podem contribuir no processo de ensino e aprendizagem dos educandos, já que viabilizam o desvelamento da indissociabilidade dos conhecimentos de ciências construídos na escola com problemas presentes na realidade dos educandos, em que os conhecimentos científicos têm um papel fundamental na compreensão e superação destes problemas.

Constatamos que a escola se configura como um dos espaços mais importantes para a reflexão e discussão dos valores, visto que a Axiologia Educacional é "a própria Axiologia Fundamental aplicada à totalidade do humano e mesmo, mais profundamente, à atualização constituinte do próprio humano, pois é a educação, na sua máxima generalidade e profundidade, que atualiza a humanidade do homem". (Patrício, 1993, p. 46). Portanto, entendemos que essa reflexão e discussão sobre os valores não se limita somente às disciplinas de Humanidades, uma vez que a educação, na perspectiva freireana, é concebida como uma totalidade imanente, em que todas as áreas do conhecimento contribuem para uma práxis transformadora que considera a realidade do educando e todas as particularidades inerentes a ela, como as crenças, costumes, história, valores etc. (Freire, 1996). 
A reflexão sobre os valores e a concepção de educação, vinculada à organização de um currículo escolar, mostra-se imprescindível quando se pretende combater a perpetuação das relações de exclusão e opressão. Essa imprescindibilidade reside no fato de que os conteúdos escolares, incluindo os conteúdos de ciências que em muitos casos são compreendidos como neutros e imparciais, possuem intrinsecamente uma ética e uma moral que podem estar configurados como mecanismos de manutenção das relações de dominação (Silva, 2004). Nesse sentido, entendemos que o sistema educativo que se pauta na Abordagem Temática Freireana contempla aspectos da Axiologia Educacional patriciana, contribuindo para um reconhecimento e fortalecimento do sistema de valores inerentes à cultura local, por meio de ações e conhecimentos significativos no currículo escolar, o que contribui para a efetivação de projetos pedagógicos libertadores.

O processo de organização das Unidades de Conhecimentos de Ciência, referente ao Tema Gerador "As riquezas naturais do bairro Iguape: entre o discurso e a prática", realizado pelas educadoras e o GEATEC, revelou aspectos como: a importância da criticidade (valor lógico) no desenvolvimento dos conhecimentos deciências que auxiliam no desvelamento crítico da realidade; a imprescindibilidade da responsabilidade pelo outro e o respeito pelas diferentes visões de mundo (valores éticos) em uma educação humanizadora; e o prazer (valor hedonístico) que decorre de um processo de ensino e aprendizagem de ciências com sentido e significado aos educandos.

Destacamos que no Ensino de Ciências é necessário considerar os aspectos axiológicos envolvidos no processo de ensino e aprendizagem das Ciências, uma vez que os sujeitos podem apresentar uma visão limitada em relação a elementos presentes na própria realidade. Essa visão limitada funda-se em valores negativos (desvalores) indicando uma compreensão acrítica da própria condição existencial (Dussel, 2013).

Organizar um programa escolar da área de Ciências que visa possibilitar a superação de uma compreensão limitada sobre a própria realidade, evidencia sua importância ao promover a construção de conhecimentos que propiciam aos educandos o desenvolvimento de uma consciência ético-crítica, para que seja possível um entendimento crítico da realidade, que envolva a multiplicidade de valores inerentes às complexidades das relações do homem com o mundo (Patrício, 1993). Ou seja, uma visão limitada, que se pauta na desvalorização da própria realidade, pode ser considerada uma situação-limite. Por isso, no desenvolvimento da Investigação Temática, é necessário observar a ausência e a presença de valores práticos, éticos, estéticos, lógicos e hedonísticos, como uma possibilidade para o entendimento de como os sujeitos compreendem a própria condição existencial no mundo, viabilizando uma organização curricular que auxilie na compreensão e superação das contradições sociais por meio de uma educação libertadora.

É de suma importância que os educadores compreendam que os objetivos da prática pedagógica e do currículo escolar estão fundados em intenções, interesses e atitudes, isto é, em valores que orientam o fazer educativo (Dussel, 1980). Reconhecer que a prática pedagógica, os conteúdos escolares, os métodos avaliativos e o currículo 
possuem uma dimensão axiológica, independente da perspectiva educacional e da área de conhecimento, faz-se necessário tendo em vista que os valores promovidos ao longo do processo de ensino e aprendizagem irão influenciar diretamente nos objetivos pedagógicos, tendo reverberações em longo prazo, uma vez que o sistema educativo trabalha com formação humana, possibilitando a preparação de cidadãos atuantes na sociedade. Assim, o projeto educacional está alinhado com o tipo de sociedade que se almeja.

\section{Agradecimentos}

Os autores agradecem ao Conselho Nacional de Desenvolvimento Científico e Tecnológico $(\mathrm{CNPq})$ pelo apoio financeiro recebido na etapa de desenvolvimento do processo formativo de professores. O primeiro autor agradece a Fundação de Amparo à Pesquisa do Estado da Bahia (FAPESB) pela concessão da bolsa de estudos; e a segunda autora agradece a CAPES pela concessão da bolsa de estudos.

\section{Referências}

Assunção, J. L. A Abordagem Temática Freireana na elaboração de um Projeto PolíticoPedagógico. Dissertação (Mestrado em Educação em Ciências). Universidade Estadual de Santa Cruz, Ilhéus, 2019.

Bezerra, B. H. S., \& Amaral, E. M. R. (2019). Identificando Compromissos Epistemológicos, Ontológicos e Axiológicos em falas de licenciandos quando discutem uma Questão Sociocientífica. Química Nova na Escola (online), 41(1), 41-54. http:// http://dx.doi.org/10.21577/0104-8899.20160137

Centa, F. G., \& Muenchen, C. (2018). O trabalho coletivo e interdisciplinar em uma reorientação curricular na perspectiva da Abordagem Temática Freireana. Revista Electrónica de Enseñanza de Las Ciencias, 17(1), 68-93.

Conti, M. A., Toral, N., \& Peres, S. V. (2008). A mídia e o corpo: o que o jovem tem a dizer? Ciência \& Saúde Coletiva, 23(1), 34-39. http://dx.doi.org/10.1590/S141381232010000400023

Cordeiro, M. D. (2016). Ciência e valores na história da fissão nuclear: potencialidades para a educação científica. Tese (Doutorado em Educação Científica e Tecnológica). Universidade Federal de Santa Catarina, Florianópolis.

Dalri, J. (2010). A dimensão axiológica do perfil conceitual. Dissertação (Mestrado em Ensino de Ciências). Universidade de São Paulo, São Paulo.

Delizoicov, D. (1982). Concepção problematizadora do ensino de ciências na educação formal: relato e análise de uma prática educacional na Guiné Bissau. Dissertação (Mestrado em Ensino de Ciências) - Universidade de São Paulo, São Paulo. 
Delizoicov, D. (1991). Conhecimento, tensões e transições. Tese (Doutorado em Educação). Faculdade de Educação da Universidade de São Paulo (FEUSP), São Paulo.

Dussel, E. (2013). Ethics of liberation: in the age of globalization and exclusion. Translated by Eduardo Mendieta et al. London: Duke University Press.

Delizoicov, D. (1977). Filosofia da libertação na América Latina. São Paulo: Edições Loyola.

Delizoicov, D. (1980). La pedagógica latinoamericana. Bogotá: Nueva América.

Freire, P. (1987). Pedagogia do Oprimido. 17. ed. Rio de Janeiro: Paz e Terra.

Freire, P. (1996). Pedagogia da autonomia: saberes necessários à prática educativa. São Paulo: Paz e Terra.

Fonseca, K. N. (2017). Investigação Temática e a Formação Social do Espaço: construção de uma proposta com professores dos anos iniciais. Dissertação (Mestrado em Educação em Ciências). Universidade Estadual de Santa Cruz (UESC), Ilhéus.

Fonseca, K. N., Milli, J. C., Solino, A. P., \& Gehlen, S. T. (2018). Milton Santos e Paulo Freire na Educação em Ciências: a Forma-Conteúdo expressa no Tema Gerador. Investigações em Ensino de Ciências (ONLINE), 23(1), 331-382. http://doi:10.22600/1518-8795. ienci2018v23n2p331

Furlan, A. (2015). Concepção de um currículo crítico: a ética como referência praxiológica. Dissertação (Mestrado em Educação). Universidade Federal de São Carlos, Sorocaba.

Gadotti, M. (2007). A escola e o professor: Paulo Freire e a paixão de ensinar. 1. ed. São Paulo: Publisher Brasil.

Hessen, J. (1974). Filosofia dos valores. Coimbra: Armênio Amado.

Lacey, H. (1998). Valores e atividade científica. São Paulo: Discurso Editorial.

Lambach, M. (2013). Formação Permanente de Professores de Química da EJA na Perspectiva Dialógico-Problematizadora Freireana. Tese (Doutorado em Educação Científica e Tecnológica). Universidade Federal de Santa Catarina, Florianópolis.

Lucas, L. B. (2014). Axiologia Relacional Pedagógica e a formação inicial de professores de Biologia. Tese (Doutorado em Educação de Ciências e Educação Matemática). Universidade Estadual de Londrina, Londrina.

Lucas, L. B., Passos, M. M., \& Arruda, S. M. (2013). Axiologia e o processo de formação inicial de professores de Biologia. Investigações em Ensino de Ciências (Online), 18(3), 645-665.

Lucas, L. B., Passos, M. M., \& Arruda, S. M. (2016). A Não Neutralidade Axiológica do Processo de Formação Inicial de Professores de Biologia. Revista Brasileira de Pesquisa em Educação em Ciências, 16(3), p. 499-520. 
Lucas, L. B., \& Passos, M. M. (2015). Filosofia dos valores: uma compreensão históricoepistemológica da ciência axiológica. Conjectura: Filosofia e Educação (UCS), 20(3), p. 123-160.

Mafra, J. F. (2007). A conectividade radical como princípio e prática da educação em Paulo Freire. Tese (Doutorado em Educação). Universidade de São Paulo, São Paulo.

Mendonça, A. R. (2016). A aposta da reorientação curricular via Tema Gerador no Projeto Parnamirim Interdisciplinar. Dissertação (Mestrado em Educação). Universidade Federal do Rio Grande do Norte, Natal.

Milli, J. C. L., Almeida, E. S., \& Gehlen, S. T. (2018). A Rede Temática e o Ciclo Temático na Busca pela Cultura de Participação na Educação CTS. Alexandria: Revista de Educação em Ciências e Tecnologia, Florianópolis, 11(1), 71-100. https://doi.org/10.5007/1982$5153.2018 \mathrm{v} 11 \mathrm{n} 1 \mathrm{p} 71$

Milli, J. C. L., Solino, A. P., \& Gehlen, S. T. (2018). A Análise Textual Discursiva na investigação do Tema Gerador: por onde e como começar? Investigações em Ensino de Ciências (ONLINE), 23(1), 200-229. http://doi:10.22600/1518-8795. ienci2018v23n1p200

Moraes, R., \& Galiazzi, M. C. (2011). Análise Textual Discursiva. In R. Moraes, \& M. C. Galiazzi (Org.), Análise Textual Discursiva: Análise de Conteúdo? Análise de Discurso? Ijuí, 2a ed. Unijuí.

Moura, W. C. (2011). Axiologia e Educação (Física): Discursos de professores e alunos em tempos de relativismo. Dissertação (Mestrado em Desporto para crianças e jovens). Universidade do Porto, Portugal.

Muenchen, C. (2010). A disseminação dos Três Momentos Pedagógicos: um estudo sobre as práticas docentes na região de Santa Maria/RS. Tese (Doutorado em Educação Científica e Tecnológica). Universidade Federal de Santa Catarina, Florianópolis.

Neres, C. A., Fonseca, K. N., Milli, J. C. L., \& Gehlen, S. T. (2016). Rede Temática: uma construção colaborativa em uma escola dos anos iniciais de Itabuna/BA. In XVIII Encontro Nacional de Ensino de Química, Florianópolis, SC.

Patrício, M. (1993). Lições de axiologia educacional. Lisboa: Universidade Aberta.

Pedro, A. P. (2014). Ética, moral, axiologia e valores: confusões e ambiguidades em torno de um conceito comum. Kriterion, Belo Horizonte, 55(130), 483-498. http://dx.doi. org/10.1590/S0100-512X2014000200002

Raicik, A. C. \& Angotti, J. A. P. (2019). A escolha teórica em controvérsias científicas: valores e seus juízos à luz das concepções Kuhnianas. Alexandria: Revista de Educação em Ciências e Tecnologia, Florianópolis, 12(1), 331-349. http://dx.doi.org/10.5007/19825153.2019v12n1p331 
Rambo, E. M. (2017). Paulo Freire: Diálogo no âmbito da Educação Infantil - Estudos de caso no município de Concordia-SC. Dissertação (Mestrado em Educação), Universidade Federal da Fronteira Sul, Chapecó, SC.

Razera, J. C. C. (2011). O desenvolvimento moral em aulas de ciências: explorando uma interface de contribuições. Tese (Doutorado em Educação Para a Ciência). Universidade Estadual Paulista Júlio de Mesquita Filho, Bauru.

Roberts, P. (2000). Education, literacy, and humanization: exploring the work of Paulo Freire. London: Bergin \& Garvey.

Santos, R. A. (2016). Busca de uma participação social para além da avaliação de impactos da Ciência-Tecnologia na Sociedade: sinalizações de práticas educativas CTS. Tese (Doutorado em Educação). Universidade Federal de Santa Maria, Santa Maria.

Scocuglia, A. C. (2008). A pedagogia social de Paulo Freire como contraponto da pedagogia globalizada. In R. Silva, J. C. Souza Neto, \& R. A. Moura. (Org.). Pedagogia Social. São Paulo: Expressão e Arte/UNESCO, 225-240.

Sena, L. M. (2010). Educação ambiental e o trabalho com valores: um estudo de caso. Dissertação (Mestrado em Educação). Universidade Estadual Paulista Júlio de Mesquita Filho, Rio Claro/SP.

Silva, A. F. G. (2004). A construção do currículo na perspectiva popular crítica: das falas significativas às práticas contextualizadas. Tese de Doutorado. Pontifícia Universidade Católica/SP, São Paulo.

Silva, A. F. G. (2013). O currículo na práxis da educação popular: projeto pedagógico interdisciplinar - tema gerador via rede temática. In M. Pernambuco, \& I. A. Paiva (Org.). Práticas Coletivas na Escola. Campinas: Mercado das Letras, 75-96.

Silva, A. F. G., \& Pernambuco, M. C. A. (2014). Paulo Freire: uma proposta pedagógica ético-crítica para a educação ambiental. In C. F. B. Loureiro, J. R. Torres (Org.) Educação Ambiental: dialogando com Paulo Freire. 1. Ed. São Paulo: Cortez.

Sousa, P. S., Solino, A. P., Figueiredo, P. S., \& Gehlen, S. T. (2014). Investigação Temática no Contexto do Ensino de Ciências: Relações entre a Abordagem Temática Freireana e a Práxis Curricular via Tema Gerador. Alexandria: Revista de Educação em Ciência e Tecnologia. 7(1), 155-177. https://doi.org/10.5007/\%25x

Stuani, G. M. (2016). Abordagem Temática Freireana: uma concepção de formação permanente dos professores de ciências. Tese (Doutorado em Educação Científica e Tecnológica). Universidade Federal de Santa Catarina, Florianópolis. 
Jefferson da Silva Santos

${ }^{\circledR}$ https://orcid.org/0000-0002-8313-4973

Universidade Estadual de Santa Cruz Ilhéus, Bahia, Brasil thomasjefferson_br@hotmail.com

Josenilda Assunção Lima

${ }^{D}$ https://orcid.org/0000-0001-6855-0381

Universidade Estadual de Santa Cruz Ilhéus, Bahia, Brasil josylimapedro@gmail.com

Leticia dos Santos Barbosa

${ }^{[}$https://orcid.org/0000-0002-1432-7130 Universidade Estadual de Santa Cruz Ilhéus, Bahia, Brasil ticiapedagogia2012@gmail.com

Simoni Tormohlen Gehlen

https://orcid.org/0000-0002-9786-3392 Universidade Estadual de Santa Cruz Departamento de Ciências Exatas e Tecnológicas Ilhéus, Bahia, Brasil stgehlen@gmail.com

Submetido em 18 de fevereiro de 2019 Aceito em 28 de outubro de 2019 Publicado em 30 de novembro de 2019 